\title{
Social networking in crop plants: Wire and wireless cross-phytobiome communications
}

\author{
Rouhallah Sharifi ${ }^{1}$ and Choong Min Ryu ${ }^{2}$ \\ ${ }^{1}$ Razi University \\ ${ }^{2} \mathrm{KRIBB}$
}

September 10, 2020

\begin{abstract}
ants share the phytobiome with other members of the ecological community by sharing their physiology. The phytobiome is a collective ecological entity that senses external and internal stimuli via its member's sensing apparatus (senome). The activated senome generates intercellular, and intra- and inter-organismal signals that induce genetically and epigenetically dependent modifications of phytobiome member transcriptomes. Ultimately, these genetic modifications alter the phenotypes of the collective phytobiome members. Mycorrhiza, epiphytic fungi, and dodder can physically transfer signals between kin and non-kin plants. Phytobiome members can release infochemicals by themselves, or modify plant volatile emissions and root exudates to act as signals for plant-plant interactions. These signals can change plant physiology and induce holobiont updates in receiver plants via a facilitative or competitive mechanism. Receiver plants eavesdrop on phytobiome cues and signals to anticipate responses to unfolding challenges. An emerging body of information in plant-plant interactions through inter-kingdom communication can be exploited in integrated crop management under field conditions. However, a holistic view is crucial for the manipulation of complex systems, such as the phytobiome, to avoid potential butterfly effects.
\end{abstract}

\section{1 ? INTRODUCTION}

Humans have empathic perceptions so that if one member is afflicted with pain, other members will become uneasy (Saadi Shirazi, 1210-1292).

Plant seeds inherit information for their lifecycles directly from their parents, although much of the genomic information has been acquired from ancestors such as ferns, bryophytes, and Cyanobacteria (SánchezBaracaldo, Raven, Pisani \& Knoll, 2017, Sharifi \& Ryu, 2018c). Plants harbor genes and signaling pathways that function during symbiosis with Cyanobacteria and Lycophytes, which can be traced back to the origins of vascular plants (Jia, Kollner, Gershenzon \& Chen, 2018, Sánchez-Baracaldo et al. , 2017, Sharifi \& Ryu, 2018c). Symbiotic relationships have continuously developed during the co-evolution of plants and microbes, and include the exchange of genetic elements, signal molecules, and nutrients (Jia et al. , 2018, Papale, Saget \& Bapteste, 2020, Sharifi \& Ryu, 2018b).

Recent reports proposed that multicellular organisms (e.g., animals and plants) and their associated unicellular organisms (e.g., microbes) could be considered as super-organisms, or holobionts (in ancient Greek, holos means whole and biont means unit of life) (Gilbert, 2019, Suarez \& Stencel, 2020). However, the definition and concept of a holobiont is still debated. We consider a holobiont as an ecological unit (assembly) of a group of organisms that gather together based on their evolutionary capability to achieve a common purpose, which is survival of the holobiont. A holobiont undergoes natural selection as a team or assembly (Gilbert, 2019, Osmanovic, Kessler, Rabin \& Soen, 2018). Members of the holobiont retain their individuality during symbiosis, but share their genetics and physiological capabilities to sustain the holobiont. The introduction and persistence of members in the holobiont is modulated by individual signaling pathways and 
innate immunity systems, especially for core animal and plant members (Carrión, Perez-Jaramillo, Cordovez, Tracanna, de Hollander, Ruiz-Buck, Mendes, van Ijcken, Medema \& Raaijmakers, 2019, Carvalhais, Dennis, Badri, Kidd, Vivanco \& Schenk, 2015, Cotton, Petriacq, Cameron, Meselmani, Schwarzenbacher, Rolfe \& Ton, 2019, Korenblum, Dong, Szymanski, Panda, Jozwiak, Massalha, Meir, Rogachev \& Aharoni, 2020, Mannaa, Han, Jeon, Kim, Kim, Park, Kim \& Seo, 2020). The holobiome includes all living organisms, their genetic materials, and their primary and secondary metabolites and molecules produced within a particular habitat (Berg, Rybakova, Fischer, Cernava, Vergès, Charles, Chen, Cocolin, Eversole \& Corral, 2020, Sharifi \& Ryu, 2017).

The microbiome includes the microbial community living in a particular habitat and their metabolites, mobile genetic elements, and relic DNA (Berg et al. , 2020). The microbiome helps the holobiont survive during biotic and abiotic stresses. The presence and abundance of specific microbial species in the microbiome change during successive phases of plant ontogeny and during biotic/abiotic stresses (Carriónet al. , 2019, Cotton et al. , 2019, Edwards, Santos-Medelln, Liechty, Nguyen, Lurie \& Eason, 2018, Gu, Wei, Wang, Friman, Huang, Wang, Mei, Xu, Shen \& Jousset, 2016). The rice microbiome changes gradually during plant development: change is dynamic during the vegetative stage but more stable during the reproductive stage (Edwards et al. , 2018). Biotic and abiotic stresses modulate the plant microbiome toward plant defense responses or plant tolerance (Cotton et al. , 2019, Dini-Andreote, 2020, Gu et al. , 2016). For example, Flavobacteriaceae and Chitinophagaceae populations increase in the endosphere of sugar beet infected with Rhizoctonia solani in suppressive soil. These bacteria produce chitinase and other cell wall degradation enzymes to suppress the pathogen (Carrión et al. , 2019).

Plants continuously perceive and generate signals resulting from interactions between plant cells and the microbiome to encounter biotic/abiotic stresses that could reduce performance or threaten survival, although the microbial members of the holobiont promote plant health (Erb, Veyrat, Robert, Xu, Frey, Ton \& Turlings, 2015, Sharifi \& Ryu, 2018c). Plants adapt to stress via sensor elicitation, signaling cascade activation, gene expression, and phenotype modification (Glazebrook, 2005, Jung, Tschaplinski, Wang, Glazebrook \& Greenberg, 2009). Signal processing time is critical for success or failure in stress responses. Plants acquired the ability to anticipate and respond to imminent dangers, which conferred ecological competence in highly dynamic ecosystems. This system is known as defense priming (Conrath, Beckers, Langenbach \& Jaskiewicz, 2015, Jung et al. , 2009). Plants can acquire early warning information through their microbiome and plant-plant signals (Gilbert \& Johnson, 2017, Vahabi, Reichelt, Scholz, Furch, Matsuo, Johnson, Sherameti, Gershenzon \& Oelmuller, 2018, Yi, Heil, Adame-Alvarez, Ballhorn \& Ryu, 2009). The plant microbiome (phytobiome) can exploit the unique capabilities of each of its members for the benefit of all members, including the mycorrhizal network, dodder, and endophytic fungi, which directly prime plant defense responses or transfer inter-plant signals (da Trindade, Almeida, Xavier, Lins, Andrade, Maia, Mello, Setzer, Ramos \& da Silva, 2019, Hettenhausen, Li, Zhuang, Sun, Xu, Qi, Zhang, Lei, Qin, Sun, Wang, Baldwin \& Wu, 2017, Vahabi et al. , 2018). The plant microbiome and macrobiome, including parasitic plant dodder and insect pests, can modify plant-derived inter-plant signals such as volatiles and root exudates (Figure 1) (Sharifi, Lee \& Ryu, 2018, Song, Sim, Kim \& Ryu, 2016). Herbivore-induced plant volatiles (HIPVs) and microbe-induced plant volatiles (MIPVs) are good examples of inter-plant signals (Heil \& Bueno, 2014, Sharifi et al., 2018).

Here, we review microbe-mediated and plant-mediated plant-plant communications that improve plant defense against pathogenic microbes. From multiple layers of plant-plant communications, we distinguished two distinct types: wired and wireless communications. Wired communication involves one plant sending a signal to another plant though direct contact via microbial structures and hyper-parasitic plant organs. This can be considered as an information highway mediating plant-plant communication. Wireless communication involves signal transfer across the space separating two plants. We investigated how wired and wireless communications affect plant defense responses. We determined that these signal transduction pathways proceeded via the following three steps: signal input (extracellular signal perception generates an endogenous signal cascade); transferring signal (direct connection from signal producer to receiver through mycorrhizal network and parasitic plants, and indirect signal translocation via plant volatile compounds and exudates); and signal output (receiver plant responses to biotic and abiotic stresses). 


\section{2? WIRED COMMUNICATION}

\section{1 ? Wired connections between clonal plants via rhizomes and stolons}

Some plants produce genetically identical but independent plants (clones) through specific organs such as rhizome and stolon (Bittebiere, Benot \& Mony, 2020, Vannier, Mony, Bittebiere, Theis, Rosenberg \& Vandenkoornhuyse, 2019). These clonal plants are two functionally independent plants that share vascular connections and physiological integration. Clones have similar microbiomes, and represent unique models in plant-plant interaction studies (Vannier et al. , 2019). Clones communicate and enhance each other's survival during biotic/abiotic stress (Karban, Wetzel, Shiojiri, Ishizaki, Ramirez \& Blande, 2014, Qian, Li, Han \& Sun, 2010, Semchenko, John \& Hutchings, 2007). The organ connecting clonal plants can be severed via natural or artificial methods to generate two physically separated plants, which become alienated with time (Chen, During \& Anten, 2012). Second- and third-order clones (ramets) display higher competition with the first ramet after severing (Karban \& Shiojiri, 2009). Physical connections via stolon and rhizome can mitigate abiotic stress by transferring/exchanging nutrients and metabolites, or by modulating resource use efficiency (Figure 1) (Roiloa, Antelo \& Retuerto, 2014). Defense signals can be transferred via phloem from older to younger ramets to induce systemic resistance in young ramets. Older ramets do not receive defense signals from younger clones due to the direction of source-sink gradient flow (Gomez \& Stuefer, 2006). In Trifolium repens, a defense signal against Mamestra brassicae larvae can be transferred to younger ramets within 35-51 h depending genotypic variation. Induced but undamaged ramets lost their resistance after 28 days (Gomez, Van Dijk \& Stuefer, 2010).Besides direct linked plant-plant via plant part, the higher parasitic plants also have an important role in wired communication to enhance plant fitness.

\section{2 ? Wired connections between independent plants via Dodder-mediated interspecific sig- naling}

Dodder is a plant holoparasite that acquires water and nutrients from host plants via the haustorium, which physically connects the parasite to its host. Dodder species have broad host range, and can interconnect several plant species or clusters of the same species (Figure 1) to generate a common dodder network. The common dodder network can be considered as an inter-plant highway that translocates large numbers of proteins, RNA, metabolites, and plant viruses over a distance of at least $100 \mathrm{~cm}$ (Hettenhausen et al. , 2017, Zhuang, Li, Song, Hettenhausen, Schuman, Sun, Zhang, Li, Song \& Wu, 2018). The common dodder network can translocate more than 1,500 proteins between soybean and Arabidopsis, and some of these proteins can localize in dodder seeds. Approximately $15-30 \%$ of dodder proteins have host origin, including transcription factors and $\mathrm{R}$ proteins that may function in signal transaction. Dodder proteins can transfer to host plant cells. Plants can anticipate future threats by receiving neighboring plant signals transferred through the common dodder network. Although there are few reports on the role of the common dodder network in inter-plant signaling, the results indicate that these transferred signals are important in biotic/abiotic stress responses. When a host of dodder plant is under abiotic stress such high salinity, dodder transfers salinity stress signals through a cluster of plants at a rate of $1.2 \mathrm{~cm}$ per min, which prime salt tolerance in neighboring receiver plants. This receiver plant priming changes the transcriptome, proline levels, and stomatal conduction, so that the receiver plant stress response becomes similar to that of the donor plant (Li, Zhang, Liu, Liu, Shen, Zhuang \& Wu, 2020).

Plants infected with different herbivorous insects transfer relatively long-distance signals to conspecific and heterospecific neighbors via the common dodder network (Hettenhausen et al. , 2017, Zhuanget al. , 2018). Myzus persica infestation reduces the contents of salicylic acid (SA) and jasmonic acid (JA) in dodder by up to $58 \%$ and $41 \%$, respectively. Aphids can modulate hormonal signaling by injecting effector proteins into dodder plants (Rodriguez \& Bos, 2013). Aphid-infested dodder induce JA but not SA in soybean hosts, and subsequent phloem sap feeding by $M$. persica and chewing by Spodoptera litura causes $41 \%$ and $20 \%$ less damage, respectively, in dodder-infected plants than in control plants. Dodder transfers signals from insectdamaged soybean to conspecific or heterospecific plants, such as tomato and Arabidopsis. Gene expression and RNA-seq analyses reveal intense transcriptome modification in receiver plants. An unknown signal can translocate between common dodder network-connected Arabidopsis plants at a rate of $1 \mathrm{~cm} / \mathrm{min}$. A wave 
of signal transduction propagated between connected Arabidopsis plants, as intracellular WRKY 40 and WRKY53 transcription factors reached maximum expression at 45 and 90 min after donor plant damage in the second and fourth plants in the cluster, respectively (Zhuang et al. , 2018).

\section{3 ? Wired connections between plants via fungal hyphae of the mycorrhizal or endophytic fungal network}

Fungi can act as messengers to transfer information between independent plants. Plant-mycorrhiza symbiosis is an ancient system that arose more than 450 million years ago (Waters, Gutjahr, Bennett \& Nelson, 2017). This symbiosis had a crucial role in land colonization by plants. Different fungal phyla have evolved different types of plant-mycorrhiza symbiosis. Arbuscular mycorrhizae (AM) fungi belong to Glomeromycota, and establish symbiotic relationships with $78 \%$ of plants, especially in grassland, tropical rainforest, and agricultural fields (Tedersoo, Bahram \& Zobel, 2020). Ectomycorrhiza (EcM) belong to several fungal phyla, and establish symbiotic relationships with $2 \%$ of plants, especially in temperate and coniferous forests (Pickles, Wilhelm, Asay, Hahn, Simard \& Mohn, 2017, Tedersoo et al. , 2020). EcM form a rhizomorph structure that can spread over several meters. There are two further types of symbiotic mycorrhiza: ericoid and orchid. Ericoid mycorrhiza belong to Phallales, Boletales, and Russulales orders of Basidiomycota, and establish symbiotic relationships with 400 plant species from the Monotropoideae subfamily of Ericaceae. These plants do not have chlorophyll and obtain $85-100 \%$ of required carbon from fungi, which are simultaneously connected to autotroph nurse trees (Min, Chang-Qin, Yong-Peng, Welti, Moreau \& Selosse, 2012, Simard, 2018). Some Brassicaceae and Proteaceae plants do not participate in mycorrhizal relationships, and are considered to be non-mycorrhizal symbiotic plants (Tedersoo et al. , 2020). These plants can interfere in the mycorrhizal establishment of other plants (Cipollini, Rigsby \& Barto, 2012). For example, Alliaria petiolata produces glucosinolate-derived exudate that suppresses the mycorrhizae of neighboring plants (Cipollini et al. , 2012).

Mycorrhizae have important roles in inter-plant nutrient transfer (especially carbon, phosphorus, and nitrogen), allelochemicals, and signal molecules. Mycorrhizae are common in soil, as $1 \mathrm{~g}$ of soil contains 10-100 meters of mycorrhizal fungi (Gilbert \& Johnson, 2017). These fungi have broad host ranges and can connect several plants from different taxa. Closely-related mycorrhiza fungi can perform anastomosis to generate a network (Figure 1), which is called a common mycorrhiza network (Deja-Sikora, Mercy, Baum \& Hrynkiewicz, 2019). Some plant species exploit the common mycorrhiza network, especially EcM, to transfer nutrients and signals and promote the establishment and survival of conspecific seedlings. Mycorrhiza colonization affects community structure and dominance of specific plant species in natural ecosystems (Bennett, Cahill \& van der Heijden, 2016, Hortal, Lozano, Bastida, Armas, Moreno, Garcia \& Pugnaire, 2017). EcM support their plant partner by transferring large amounts of organic carbon, changing the hyphosphere microbiome, and directly or indirectly suppressing plant pathogens (Chen et al. , 2012, Liang, Johnson, Burslem, Yu, Fang, Taylor, Taylor, Helgason \& Liu, 2020, Pickles et al. , 2017). A comprehensive study performed over 10 years in 1200 plots in a Chinese forest reported that EcM acts as a mediator in supporting the establishment and survival of young plants by adult nurse conspecifics. Inhibiting the EcM connection between plants using a $0.5-\mu \mathrm{m}$ mesh markedly reduced seedling survival. The abundance of plant pathogenic fungi also decreased in EcM-colonized plots (Liang et al. , 2020).

Plants exploit mycorrhizae fungi for long-distance transfer of plant signals and allelochemicals. Tagetes tenuifolia secrete the lipophilic allelopatic compound thiophenes and the hydrophilic allelopatic compound imazamox, which diffuse more than $12 \mathrm{~cm}$ via the common mycorrhiza network (Barto, Hilker, Muller, Mohney, Weidenhamer \& Rillig, 2011). Mycorrhizae fungi can translocate defense signals to neighboring unstressed plants, similarly as dodder. Tomato plants infected with the nectrotrophic pathogenic fungus Alternaria solani transfer a signal to non-infected neighbors at $18 \mathrm{~h}$ post-inoculation via mycorrhizae hypha. In those receiver plants, the relative expression levels of defense-related genes such as phenylalanine ammonialyase (PAL), lipoxygenase, polyphenol oxidase, and pathogenesis-related proteins (PR1, PR2, and PR4) were the same as those in the donor plants (Song, Zeng, Xu, Li, Shen \& Yihdego, 2010). Signal transduction via the common mycorrhiza network also has been detected for herbivore-damaged plants (Babikova, Gilbert, 
Bruce, Birkett, Caulfield, Woodcock, Pickett \& Johnson, 2013, Song, Ye, Li, He, Zhu-Salzman, Wang, Su, Luo \& Zeng, 2014).

Stressed plants can recruit mycorrhizae by regulating strigolactone signaling. Plant strigolactones are multifunctional hormones with pivotal roles in plant ecological relationships: strigolactones promote mycorrhiza spore germination and hyphal branching (Waters et al. , 2017); modify fungal and bacterial populations including those of plant pathogens in the rhizosphere (Carvalhais, Rincon-Florez, Brewer, Beveridge, Dennis \& Schenk, 2019, Liu, Rice, Lopes, Grewal, Lebeis, Hewezi \& Staton, 2020); establish cross-talk with defenserelated hormones such as JA, SA, and ABA; and modulate plant resistance to different plant pathogenic fungi and bacteria (Lopez-Raez, Shirasu \& Foo, 2017). Pathogen infection can induce plants to modulate strigolactones biosynthesis to recruit mycorrhiza and other beneficial microbes.

Fungal signal transduction is not exclusive to mycorrhizae. Other mutual and pathogenic fungi with longterm endophytic relationships with plants have the potential to transfer signals between plants. Some soil fungi can serve as a bridge between host plants. For example,Piriformospora indica transfers signals from infectedArabidopsis to neighboring Arabidopsis plants.Alternaria brassicae activates JA pathways in infected focal plants. By contrast, endophytic fungi convert a specific JA signal to generate an ABA signal in neighboring (receiver) plants (Vahabi et al. , 2018).

Fungi serve as vectors for the transfer of plant viruses among plants. Although plants and fungi are not phylogenetically related, they can be infected by phylogenetically-related viruses (Roossinck, 2019). Some plant viruses propagate in the fungal cytosol and transfer between host plants based on the host range of both fungi and viruses. A virus from the saprophytic endophyte Penicillium aurantiogriseum replicates in the host plant (Nerva, Varese, Falk \& Turina, 2017). Cucumber mosaic virus is a broad-range virus that can survive in the pathogenic fungus Rhizoctonia solani, which has a broad host range. $R$. solani transfers this virus to a neighboring host (Andika, Wei, Cao, Salaipeth, Kondo \& Sun, 2017). There is evidence that plant virus enters fungal spores and achieves long-distance dissemination via wind dispersal of the fungal spores. Cryphonectria transferCryphonectria hypovirus 1 to tobacco, which subsequently propagates and spreads systemically throughout the plant with the help of Tobacco mosaic virus (TMV) movement protein. TMV also enters fungi and propagates with the help of Cryphonectria hypovirus 1, which can spread to other hosts via fungal spores (Bian, Andika, Pang, Lian, Wei, Niu, Wu, Kondo, Liu \& Sun, 2020).

\section{3 ? WIRELESS COMMUNICATION: SIGNAL INPUT-TRANSFER-OUTPUT MODEL}

Plants normally release volatile and non-volatile chemicals that can be exploited by other plants as a source of signal molecules (infochemicals). Here, we discuss how these plant infochemicals can be modulated by microbes, insects, and environmental stimuli. These infochemicals diffuse via air and soil pores to reach neighbor plants. Receiver plants can amplify the released infochemical signals to expand the effective infochemical signaling zone. Infochemicals perceived by the receiver plants can act as kin recognition signals, growth inhibitors (allelopathy), growth stimulators, and defense signals (Karban, Shiojiri, Ishizaki, Wetzel \& Evans, 2013, Kong, Zhang, Li, Xia, Yang, Meiners \& Wang, 2018, Sharifi et al. , 2018, Sharifi \& Ryu, 2018b). Infochemicals can directly change the transcriptome and physiology of receiver plants to prime for imminent threats, or they may indirectly change the plant microbiome in neighboring plants through a facilitative or competitive mechanism (Carvalhais et al. ,2015, Mannaa et al. , 2020, Vannier, Bittebiere, Mony \& Vandenkoornhuyse, 2020).

\section{1 ? Wireless signal input}

\subsection{1 ? Constitutive release of infochemicals as information sources}

Plants continuously release a profile of volatile organic compounds (VOCs) and non-VOCs to the root and atmosphere (Table 1). These chemical profiles, concentrations, and release time courses function as signals of plant presence and health status. Constitutive release of specific chemical signatures can be exploited by neighbor organisms to determine the presence and identity of neighboring plants. Receiver plants recognize the degree of phylogenetical relationship of neighbor plants to discriminate kin and non-kin 
plants (Delory, Delaplace, Fauconnier \& du Jardin, 2016, Palmer, Ali, Yang, Parchami, Bento, Mazzella, Oni, Riley, Schneider \& Massa, 2016). Chemicals such as ethylene released from healthy plants are sensed by insects, parasitic plants, and neighboring plants as a cue to change their behavior (Pierik, Visser, de Kroon \& Voesenek, 2003, Robert, Erb, Duployer, Zwahlen, Doyen \& Turlings, 2012, Runyon, Mescher \& De Moraes, 2010). For example, exposing potato to healthy onion changes potato volatiles, which are repellent to an aphid pest and attractive to the aphid predator ladybird beetle (Ninkovic, Dahlin, Vucetic, Petrovic-Obradovic, Glinwood \& Webster, 2013, Vucetic, Dahlin, Petrovic-Obradovic, Glinwood, Webster \& Ninkovic, 2014). ( $E$ )-nerolidol and (3E ,7E )-4,8,12-trimethyl-1,3,7,11-tridecatetraene were the primary effective volatiles released by exposed potato plants (Vuceticet al. , 2014). In most cases, signals from healthy plants can affect neighboring plants by modifying biomass allocation, lateral root formation, and chlorophyll and phenolic compound biosynthesis, or directly inhibiting seed germination (Delory et al. , 2016, Takigahira \& Yamawo, 2019). The sagebrush volatile compounds methyl jasmonate, camphor, 1,8cineol, $\alpha$-thujone, and nerol inhibit the germination of Nicotiana attenuate seeds (Jassbi, Zamanizadehnajari \& Baldwin, 2010).

Some plant infochemicals are released primarily by healthy plants and can be considered as a marker of plant health status. Isoprene emission levels are linked to plant health and photosynthetic efficiency. The reduction of isoprene emission after pest and disease attacks is considered as a marker for plant stress (Copolovici, Kannaste, Pazouki \& Niinemets, 2012, Jiang, Ye, Veromann \& Niinemets, 2016, Toome, Randjärv, Copolovici, Niinemets, Heinsoo \& Luik, 2010). Isoprene alleviates plant oxidative stress (van Doorn, Merl-Pham, Ghirardo, Fink, Polle, Schnitzler \& Rosenkranz, 2020). Neighboring plants can decode the information signals contained in the time course of VOC emission, spatiotemporal chemical stability, location of emission, and emission quantity (Erb et al. , 2015, Jiang et al. , 2016, Piesik, Pańka, Jeske, Wenda-Piesik, Delaney \& Weaver, 2013).

\subsection{2 ? Microbes and insects induce the emission of specific plant volatiles}

Microbes and insects modulate plant volatile emission dynamics by decreasing some VOCs and increasing others, or by inducing de novo VOC synthesis (Table 1). Plant volatiles are produced by several metabolic pathways, including plastidic methylerythritol phosphate and cytosolic mevalonic acid pathways (terpenoid compounds), shikimic acid pathways (benzoid and phenylpropanoid compounds), and oxylipin pathways [green leaf volatiles (GLVs)] (Bouwmeester, Schuurink, Bleeker \& Schiestl, 2019). The emitted VOC profile is related to the plant genotype, organ, and type of biotic/abiotic trigger. Different comparative triggers (e.g., chewing vs. sucking/piercing, biotroph vs. necrotroph, host vs. non-host pathogens, and saprophytic beneficial vs. parasitic pathogenic microbes) elicit distinct bouquets of VOCs, including the quantity and quality of each compound and its emission time course (Castelyn, Appelgryn, Mafa, Pretorius \& Visser, 2014, Klimm, Weinhold \& Volf, 2020, Qawasmeh, Raman \& Wheatley, 2015, Quintana-Rodriguez, Morales-Vargas, Molina-Torres, Ádame-Alvarez, Acosta-Gallegos, Heil \& Flynn, 2015, Sharifi et al. , 2018). VOC profiles are conventionally defined based on the triggers, including HIPVs, oviposition-induced plant volatiles, MIPVs, and stress-induced plant volatiles (Kessler \& Heil, 2011, Sharifi et al. , 2018). These categories normally contain all of the above-mentioned VOC groups, but the quantity/quality and emission time course for each compound carries specific information. GLVs are categorized as HIPVs, especially for chewing insects, but GLVs also are emitted from microbial pathogen-infected plants (Ameye, Allmann, Verwaeren, Smagghe, Haesaert, Schuurink \& Audenaert, 2018). Rust disease disrupts the epidermis and induces the release of high amounts of GLVs (Jiang et al. , 2016). By contrast, chewing insects feeding on maize root did not elicit the emission of GLVs, and maize root did not respond to GLVs (van Doan, Züst, Maurer, Zhang, Machado, Mateo, Ye, Schimmel, Glauser \& Robert, 2020).

Plants emit VOCs in response to signaling between plants and Invaders. Plant VOC profiles were altered by pathogen-associated molecular patterns (PAMPs), herbivore-associated molecular patterns (HAMPs), damage-associated molecular patterns (DAMPs), effector proteins, and microbial volatile compounds (Figure 2) (Ameye et al. , 2018, Bouwmeester et al. , 2019, Rybakova, Rack-Wetzlinger, Cernava, Schaefer, Schmuck \& Berg, 2017, Sharifi et al. , 2018, Wu, Qi, Li, Tian, Gao, Wang, Ge, Yao, Ren, Wang, Liu, Kang, Ding \& Xie, 
2017). These elicitors activate defense-related hormones (e.g., JA, SA, and their cross-talk), which in turn activate metabolic pathways that produce the main VOC groups. HAMPs such as volicitin, caeliferins, and $\beta$-glucosidase modify the volatile profiles in several plants (Alborn, Turlings, Jones, Stenhagen, Loughrin \& Tumlinson, 1997, Alborn, Hansen, Jones, Bennett, Tumlinson, Schmelz \& Teal, 2007, Hopke, Donath, Blechert \& Boland, 1994). These compounds can induce or suppress specific groups of volatiles to attract or repel parasitoids to host plants. Well-adapted maize caterpillars (Spodoptera frugiperda) suppress HIPVs in maize, but not in cotton (De Lange, Laplanche, Guo, Xu, Vlimant, Erb, Ton \& Turlings, 2020). In some plant pathogens, PAMPs (e.g., flg22, laminarin, and glucan) and effector proteins (e.g., 2b) can modify plant VOCs (Chalal, Winkler, Gourrat, Trouvelot, Adrian, Schnitzler, Jamois \& Daire, 2015, Leitner, Kaiser, Rasmussen, Driguez, Boland \& Mithöfer, 2008, Sobhy, Bruce \& Turlings, 2018, Tu, Yang, Xu, Chen, Luo, Zhu, Chen \& Yan, 2017, Tungadi, Groen, Murphy, Pate, Iqbal, Bruce, Cunniffe \& Carr, 2017). PAMPs, HAMPs, and effector proteins are perceived by pattern recognition receptors and $\mathrm{R}$ proteins in plants, and subsequently activate basal and effector-triggered plant immune responses (Bonaventure, VanDoorn \& Baldwin, 2011, Glazebrook, 2005).

Insertion of single $\mathrm{R}$ protein and its position in the genome can significantly change the emission of volatiles (Figure 2) (Lazebnik, Tibboel, Dicke \& van Loon, 2017). Subsequent signaling pathways (e.g., SA- and JA-dependent pathways) leading to systemic resistance in inoculated and neighboring plants have important roles in volatile biosynthesis (Orlovskis \& Reymond, 2020, Wenig, Ghirardo, Sales, Pabst, Breitenbach, Antritter, Weber, Lange, Lenk, Cameron, Schnitzler \& Vlot, 2019). ENHANCED DISEASE SUSCEPTIBILITY1 (EDS1) and AvrRpm1 are essential factors in systemic acquired resistance and important regulators of VOCs synthesis in Arabidopsis (Bichlmeier, 2017). Monoterpenes such as $\alpha$ - and $\beta$-pinene also induce systemic resistance through EDS1, SA INDUCTION-DEFICIENT 2 (SID2), and NONEXPRESSOR OF PR GENES 1 (NPR1) proteins (Figure 3) (Bichlmeier, 2017). Thus, any biological and chemical modulator of plant resistance can change the VOC profile or prime VOC release in response to stress. Pseudomonas protegensstrain CHA0 did not change $\beta$-caryophyllene emission or expression of the $\beta$-caryophyllene synthase gene, but primed them in response to maize beetle Diabrotica balteata (Chiriboga, Guo, Campos-Herrera, Röder, Imperiali, Keel, Maurhofer \& Turlings, 2018). Bacterial pathogens Pseudomonas syringae directly induce the emission of 1-undecanol and $(Z)$-3-hexenol volatiles in common bean, which repel spider mite $(T e$ tranychus urticae ) (Karamanoli, Kokalas, Koveos, Junker \& Farré-Armengol, 2020). Thus, signal cross-talk during simultaneous plant infestation with herbivores and pathogens (Eberl, Hammerbacher, Gershenzon \& Unsicker, 2018, Lazebnik et al. , 2017, Peñaflor \& Bento, 2019) or co-infestation with two pests (Kroes, Weldegergis, Cappai, Dicke \& van Loon, 2017, Zhang, Broekgaarden, Zheng, Snoeren, van Loon, Gols \& Dicke, 2013) can modulate VOC emissions and attract pests and their parasitoids.

\section{2? Wireless signal transfer}

Plant infochemicals can diffuse around the elicited plant (producer), and are amplified by receiver plants to expand their effective zone. Infochemicals can diffuse distances of a few centimeters to several meters according to their chemical structure and vectors such as mycorrhiza and dodder. Wheat infected by Fusarium culmorumtransfers signals to neighbor plants located 1-3 meters distant. However, there is a negative correlation between distance and response intensity in the receiver plant. Several studies show that receiver plants also propagate signals and act as nodes in inter-plant signaling (Chen, Yang, Chen, Luo, Cui, Yan \& Gerwick, 2019a, Piesik et al. , 2013, Wenig et al. , 2019). Thus, neighboring plants amplify signals in clusters of receiver plants. However, the regulation of induced signaling pathways involved in infochemical synthesis in receiver plants requires time, which results in a wave of infochemical synthesis and metabolic responses in receiver plants. Falik, Mordoch, Ben-Natan, Vanunu, Goldstein and Novoplansky (2012) observed that osmotic stress in Pisum sativum activated stomatal closure in the focal plant and the next three plants in the cluster within $1 \mathrm{~h}$, whereas more distant plants responded after $1 \mathrm{~h}$. In this study, focal plant stomata remained closed for $24 \mathrm{~h}$, whereas receiver plants opened their stomatal apertures because they did not directly encounter osmotic stress. Receiver plants did prepare for imminent osmotic stress, with the ability to return to a naive state if the stress was resolved. Weed plants use stress signals from $P$. sativum neighbors to improve their acclimation (Falik et al. ,2012). (Wenig et al. , 2019) showed that monoterpenes such as 
$\alpha$ - and $\beta$-pinene act as immunity-inducing signals between plants (Figure 3). Systemic acquired resistance (SAR) is an SA-mediated induced resistance in systemic plant tissues that is effective against a broad range of plant pathogens (Wenig et al. , 2019). LEGUME LECTIN-LIKE PROTEIN1 (LLP1) is a predicted lectin that acts in the recognition of SAR signals, which also regulate intra- and inter-plant monoterpene synthesis. In the non-vascular marine alga Pyropia haitanensis, the 1-octone-3-ol plant-plant defense signal can self-stimulate in receiver plants and activate SA hormones (Chen et al. , 2019a).

\section{3 ? Wireless signal output: Receiver plant response to biotic/abiotic stresses}

The transferred signal is perceived by neighboring (receiver) plants and augments biotic/abiotic stress resistance responses (Table 1). VOC-mediated plant stress responses have been demonstrated in numerous studies, although the ethylene receptor ETR1 is the only plant VOC receptor identified to date (Chang, Kwok, Bleecker \& Meyerowitz, 1993). Future research may discover additional receptors to plant VOCs. Recent studies identified different mechanisms whereby receiver plants perceive VOCs from neighbor plants. VOCs can be absorbed by a wax layer on the epidermal cell, which traps VOCs and slowly releases them to attract or repel herbivores and their parasitoids and entomopathogens (Camacho-Coronel, Molina-Torres \& Heil, 2020, Lin, Hussain, Avery, Qasim, Fang \& Wang, 2016). Some trapped volatiles such as methyl salicylate (MeSA), MeJA, and indole can be converted to the active plant hormones SA, JA, and indole-3acetic acid (IAA), respectively (Figure 2,3) (Bailly, Groenhagen, Schulz, Geisler, Eberl \& Weisskopf, 2014, Rivas-San Vicente \& Plasencia, 2011). Some enzymes metabolize trapped volatiles such as $(Z)$ )-3-hexenol to the more active derivative $(Z$ )-3-hexenylvicianoside (Sugimoto, Matsui, Iijima, Akakabe, Muramoto, Ozawa, Uefune, Sasaki, Alamgir \& Akitake, 2014). Some GLVs induce plasma membrane potential depolarization in receiver plants, thereby activating reactive oxygen species (ROS) and calcium signaling (Figure 2) (Zebelo, Matsui, Ozawa \& Maffei, 2012).

The perception of VOCs modifies the transcriptome, proteome, and metabolome in receiver plants (Kwon, Ryu, Lee, Park, Han, Lee, Lee, Chung, Jeong, Kim \& Bae, 2010, van Dam \& Bouwmeester, 2016, Zhang, Kim, Krishnamachari, Payton, Sun, Grimson, Farag, Ryu, Allen, Melo \& Pare, 2007). In some cases, VOCs do not significantly change gene expression profiles and metabolic activity, but prime the plant to respond more rapidly and robustly to upcoming threats (Paschold, Halitschke \& Baldwin, 2006, Quintana-Rodriguez et al. , 2015). Plant volatile $(Z)$-3-hexenyl acetate directly induces JA- and abscisic acid-related gene expression, whereas indole primes these genes in maize against Spodoptera littoralis (Hu, Ye \& Erb, 2019). Several studies report that primed plants activate defense-related pathways based on the attacker identity rather than the inducer (Moreira, Nell, Katsanis, Rasmann \& Mooney, 2018, Sharifi \& Ryu, 2017). For example, VOCs from plants infested with general or specialized herbivores activate similar defense pathways and VOC emission profiles in healthy neighbors. By contrast, primed receiver plants mount a specific set of defense mechanisms based on the type of attacker (Moreira et al. , 2018). Infochemicals from neighbor plants can activate master regulatory systems involved in plant innate immunity, including leucine-rich repeat-receptor-like kinase, mitogen-activated protein kinases, WRKY transcription factors, and systemic acquired resistance (Figure 2, 3) (Dombrowski, Kronmiller, Hollenbeck, Rhodes, Henning \& Martin, 2019, Dombrowski \& Martin, 2018, Lee, Kim, Lee, Ahn \& Ryu, 2020, Mirabella, Rauwerda, Allmann, Scala, Spyropoulou, Vries, Boersma, Breit, Haring \& Schuurink, 2015, Weniget al. , 2019, Ye, Glauser, Lou, Erb \& Hu, 2019). D-Lactic acid secreted by the microalga Chlorella fusca primed defense inArabidopsis thaliana against Pseudomonas syringae pv. tomato DC3000 by increasing the expression of WRKY transcription factors and cysteine-rich receptor-like kinases, and induced both SA- and JA-dependent pathways (Lee et al. , 2020).

In inter-plant communication, VOCs modulate receiver plant physiology and directly or indirectly affect other plant holobiome members. VOCs captured by receiver plant wax display fungicidal and bactericidal activity for several days (Camacho-Coronel et al. , 2020). GLVs and terpenoid volatiles have strong fungicidal and bactericidal activityin vitro and in planta (Huang, Sanchez-Moreiras, Abel, Sohrabi, Lee, Gershenzon \& Tholl, 2012, Pontin, Bottini, Burba \& Piccoli, 2015, Quintana-Rodriguez et al. , 2015). VOCs can alter parasitoid attraction and entomopathogenic fungi performance in both donor and receiver plants (Desurmont, 
Xu \& Turlings, 2016, Lin et al. , 2016, Xu, Desurmont, Degen, Zhou, Laplanche, Henryk \& Turlings, 2016). VOC emission in aboveground and below-ground parts may attract or repel herbivores and plant pathogenic nematodes (Ali, Alborn \& Stelinski, 2011, D'Alessandro, Erb, Ton, Brandenburg, Karlen, Zopfi \& Turlings, 2014, Rasmann, Kollner, Degenhardt, Hiltpold, Toepfer, Kuhlmann, Gershenzon \& Turlings, 2005).

Root exudates act as critical triggers to activate resistance in neighboring plants by diffusing through the soil to neighboring roots (Table 1). Root exudates such as SA transfer the SAR signal to neighboring plants and synchronize their microbiomes (Kong, Song, Sim \& Ryu, 2020, Orlovskis \& Reymond, 2020, Song et al. , 2016). Plants exploit microbiome adaptation to facilitate conspecific survival according to kin selection theory, or to compete for heterospecificity. Airborne signals from wound-damaged plants regulated the ALMT1 transporter in receiver Arabidopsis plants to release malic acid into the rhizosphere (Figure 3). Malic acid recruits B. subtilis to colonize Arabidopsis roots and induce systemic resistance to different stresses (Rudrappa, Czymmek, Pare \& Bais, 2008, Sweeney, Lakshmanan \& Bais, 2017). A (-)-loliolide root exudate at a physiological concentration of $5 \mathrm{nmol} \mathrm{g}^{-1}$ soil induces the release of the benzoxazinoid compound 2,4-dihydroxy-7-methoxy-1,4-benzoxazin-3-one (DIMBOA) exudate from wheat roots (Kong et al. , 2018). DIMBOA is a putative allelochemical with several other roles in the rhizosphere. DIMBOA regulates the root metabolome and exudation, which have important roles in shaping the root microbiome (Cotton et al. , 2019, Kudjordjie, Sapkota, Steffensen, Fomsgaard \& Nicolaisen, 2019). DIMBOA-treated plants recruit specific bacterial families and species such as Pseudomonas putida, thereby increasing plant resistance to several stresses (Neal \& Ton, 2013). P. fluorescens increases DIMBOA and primed resistance against the fungal pathogen Setosphaeria turcica in maize (Zhou, Ma, Lu, Zhu \& Yan, 2020). The populations of bacterial plant pathogens such as Xanthomonadaceae and Agrobacterium tumefaciens decreased in benzoxazinoid-treated plants (Cotton et al. , 2019, Kudjordjieet al. , 2019).

Any change in cumarin, sesquiterpenes, and diadzein by airborne signals and root exudates will change plant microbiomes (Chen, Jiang, Liu, Liu, Zhao, Liu, Gan, Hallab, Wang, He, Ma, Zhang, Jin, Schranz, Wang, Bai \& Wang, 2019b, Okutani, Hamamoto, Aoki, Nakayasu, Nihei, Nishimura, Yazaki \& Sugiyama, 2020, Stringlis, Proietti, Hickman, Van Verk, Zamioudis \& Pieterse, 2018). Activation of defense hormones (e.g., JA and SA) by airborne signals (e.g., MeSA, 3-pentanol, or effectors of aphid/whitefly pest) induces microbiome adaptation in plants (Lee, Lee \& Ryu, 2012, Mannaa et al. , 2020, Song, Choi \& Ryu, 2015, Yang, Yi, Kim, Lee, Lee, Ghim \& Ryu, 2011). Microbiome adaptation in these examples reduces disease severity caused by several plant pathogens and pests, probably by recruiting beneficial bacteria such as $B$. subtilis (Leeet al. , 2012, Song et al. , 2015). The rhizosphere microbiome also modulates root metabolism and exudation by azelaic acid as a potential signal molecule (Figure 3) (Korenblum et al. , 2020). Activation of the two JA pathway branches differentially shape the root microbiome. The Arabidopsis mutants myc2 andmed25 alter root exudate (Figure 3). Similar changes in some categories of root exudate were observed in mutants of both branches, but some root exudates were differentially synthesized. Clostridiales were abundant but declined in mutants of both branches. Bacillus, Lysinibacillus, and Streptomyces populations increased in the med25 mutant, whereas the Enterobacteriaceae population increased in the myc2 mutant (Carvalhais et al. , 2015). Med25 has an important role in regulating density recognition in Arabidopsis and changing root architecture by increasing root response to auxin (Munoz-Parra, Pelagio-Flores, RayaGonzalez, Salmeron-Barrera, Ruiz-Herrera, Valencia-Cantero \& Lopez-Bucio, 2017).

\section{4 ? Acoustic and electric signals}

Plants utilize acoustic and electric signals as internal and inter-plant signals. A sound vibration signal can be generated by a herbivore walking on the plant, breaking trichomes, chewing the plant, and even by water stress (Caicedo-Lopez, Contreras-Medina, Guevara-Gonzaleza, Perez-Matzumotob \& Ruiz-Ruedab, 2020, Kollasch, Abdul-Kaf, Body, Pinto, Appel \& Cocroft, 2020). Pest species might be discriminated based on the vibration frequency they produce (Kollasch et al. , 2020). Perception of a sound vibration signal modifies plant epigenetics, transcriptome, proteome, and metabolome (Ghosh, Mishra, Choi, Kwon, Won Bae, Park \& Bae, 2016, Jung, Kim, Jung, Jeong \& Ryu, 2020). Sound vibration signal perception modulates defense hormones such as SA, leading to activation of MAPKs, MYBs, and transcription factors (Body, Neer, C., 
Lin, Vu \& Cocroft, 2019, Ghosh et al. , 2016). This upregulation of key enzymes and secondary metabolites, including catalase and PAL, increases the biosynthesis of phenols, alkaloids, terpenes, and oxylipin-derivative VOCs (Body et al. , 2019, Ghoshet al. , 2016, Kollasch et al. , 2020). These metabolites enhance plant resistance or act as signals in plant-plant communication. Jung et al. (2020) reported that sound vibration induces resistance against the root pathogen Ralstonia solanacearum by modulating cytokinin signaling, increasing aliphatic glucosinolate biosynthesis through epigenetic DNA methylation by H3K27me3, and improving cell wall reinforcement by downregulating miR397b suppression of lignin accumulation-related transcripts. Vibration sensing is an evolutionarily ancient system that arose before vascular plants emerged, as microalga also have mechanosensory proteins that respond to vibration (Paika, Jinb, Simc \& N.L., 2018). Electric signals, primarily $\mathrm{Ca}^{2+}$ signaling, have important roles in intra- and inter-plant signaling (Choi, Miller, Wallace, Harper, Mittler \& Gilroy, 2017, de Toledo, Parise, Simmi, Costa, Senko, Debono \& Souza, 2019, Simmi, Dallagnol, Ferreira, Pereira \& Souza, 2020). The oomycete pathogen Pythium aphanidermatum exploits electric signals to target host roots (Van West, Morris, Reid, Appiah, Osborne, Campbell, Shepherd \& Gow, 2002). Both acoustic and electric signals have high transmission speed and good potential for use in precision agriculture (Choi et al. , 2017, Kollasch et al. , 2020).

\section{5 ? Field applications}

Although these previous studies have increased our understanding of the signals and mechanisms involved in plant-plant communication, the ultimate goal is to transfer this knowledge to the agricultural field. Field applications can leverage the intrinsic potential of inter-plant signaling by intercropping or rotating crops according to lab results, or by eliciting plant-plant communication with biological and chemical elicitors. Plant defense inducers can be applied to induce volatile emission and trigger plant immunity against insect pests and microbial pathogens (Table 1). MIPVs and HIPVs contain VOCs that inhibit pathogen growth and prime resistance in neighboring plants (Quintana-Rodriguezet al. , 2015, Sharifi et al. , 2018). Inoculating some plant rows in a field with non-pathogenic strains of plant pathogens, MAMPs, or HAMPs can induce VOCs release and reduce disease severity in all plants in the field. Grapevine inoculation with a sulfated laminarin MAMP increases the emission of terpenes such as $(E, E)$ - $\alpha$-farnesene, $\beta$-caryophyllene, and trans- $\beta$-ocimene, and subsequently increases resistance to downy mildew disease. VOCs release and disease resistance are significantly positively correlated (Chalalet al. , 2015), and the inter-plant signaling activity of these compounds on neighboring plants has been reported elsewhere (Lazazzara, Bueschl, Parich, Pertot, Schuhmacher \& Perazzolli, 2018, Quintana-Rodriguez et al. , 2015). The flg22 MAMP significantly induces the oxylipin volatiles nonanal, heptanal, and hendecanal (Tuet al. , 2017). Nonanal is an inter-plant signal that induces systemic resistance against plant pathogens (Yi et al. , 2009).

Inter-plant infochemicals can be applied to volatile emission and trigger immune responses (Ameye, Audenaert, De Zutter, Steppe, Van Meulebroek, Vanhaecke, De Vleesschauwer, Haesaert \& Smagghe, 2015). The ( $Z$ )-3-hexenyl acetate GLV primes JA-dependent signaling againstFusarium graminearum in wheat (Ameye et al. , 2015). Indole primes the expression of JA-dependent genes and increases JA synthesis against fall armyworm (Spodoptera frugiperda) in rice (Yeet al. , 2019). Some infochemicals may induce disease susceptibility depending on the pathosystem. GLVs induce maize susceptibility against Colletotrichum graminicola by suppressing SA-dependent pathways (Gorman, Christensen, Yan, He, Borrego \& Kolomiets, 2020). Plant growth-promoting and endophytic bacteria can induce plant volatiles synthesis to attract parasitoids and entomopathogens (Bell, Naranjo-Guevara, Santos, Meadow \& Bento, 2020, Disi, Mohammad, Lawrence, Kloepper \& Fadamiro, 2019, Maggini, Bandeira Reidel, De Leo, Mengoni, Rosaria Gallo, Miceli, Biffi, Fani, Firenzuoli, Bogani \& Pistelli, 2020). By contrast, there is an example that endophytic microbes do not have a significant effect on plant VOCs profiles and the behavior of herbivores and their parasitoids (Moisan, Lucas-Barbosa, Villela, Greenberg, Cordovez, Raaijmakers \& Dicke).

Plant-plant communication can be enhanced by introducing fungal networks into the soil between plants and by triggering fungal spore germination and root colonization with strigolactones and beneficial bacteria. Mycorrhiza and endophytic fungi such as Piriformospora indica can transfer infochemical signals between plant species (Songet al. , 2014, Vahabi et al. , 2018). Soil inoculation with these fungi or promoting their 
populations by conservative and organic agriculture can improve inter-plant signaling and plant priming for imminent challenges. Soil disturbance in intense tillage systems negatively affects mycorrhizae communities (Wang, Li, Li, Zhao \& Liao, 2020b). Mycorrhiza colonization is controlled by strigolactones and phosphorus availability (Lopez-Raez et al. , 2017, Waters et al. , 2017). Thus, reduced application of phosphorus fertilizers and increased application of phosphate-solubilizing bacteria and mycorrhiza can improve plant colonization by mycorrhiza. Beneficial microbes also can promote root colonization by mycorrhiza even in non-mycorrhiza plants (Poveda, Hermosa, Monte \& Nicolás, 2019).

Plant-plant communication can be maximized by managed intercropping to locate aboveground and belowground plant parts in close proximity to chemicals released by neighbor plants, which can directly inhibit the germination and growth of pathogenic fungi and bacteria or repel herbivores from fields (Lazazzara et al. , 2018, Quintana-Rodriguez et al. , 2015, Yang, Zhang, Qi, Mei, Liao, Ding, Deng, Fan, He, Vivanco, Li, Zhu \& Zhu, 2014, Zhou, Cen, Tian, Wang \& Zhang, 2019). Volatiles from resistant cultivars contain volatiles that can directly inhibit pathogen growth or induce systemic resistance in neighbor susceptible cultivars (Lazazzara et al. , 2018, Quintana-Rodriguez et al. , 2015). In some cases, a "bait" species can be planted in field borders to attract herbivores away from the main crop via HIPV release. Inter-plant signals can suppress plant pathogens directly or indirectly through microbiome adaptation. Intercropping of aerobic rice and watermelon reduces disease severity ofFusarium oxysporum in watermelon (Ren, Su, Yang, $\mathrm{Xu}$, Huang \& Shen, 2008). Rice root exudates reduce pathogen spore germination up to $41 \%$ and alter the root microbiome community structure in favor of Actinomycetes. Similarly, corn can act as a biological wall between pepper rows to inhibit Phytophthora capsici growth and promote the root microbiome (Yang et al. , 2014). DIMBOA is a density-dependent allelochemical that suppresses plant pathogens in densely cropped maize rows. Intercropped plants can emit infochemicals that alter the transcriptomes of neighboring plants to cope with pathogens. RNA-seq results suggest that tall fescue root exudate containing putrescine and cyclohexane-1,2-diol stimulates the expression of genes related to defense hormones and pathogenesis-related proteins in tomato, and reduces stem rot disease (Zhou et al. , 2019).

Plant debris functions as a modulator and infochemical for the next plant generation and rhizosphere microbiome. Infochemicals can remain in the ecosystem after plant death or harvest and act as signals for the next crop generation. Infochemicals have different chemical stabilities under different conditions. Plant debris in minimum-tillage and no-tillage systems may enhance slow-release of infochemicals. Plant debris can affect the next crop by modifying the soil microbiome community and activity, by increasing soil fertility, or by acting as an infochemical source (Veen, Fry, ten Hooven, Kardol, Morriën \& De Long, 2019, Wang, Wu, Wang, Alabady, Parson, Molumo \& Fankhauser, 2020a). Plant debris from root and aerial parts contains information about plant identity, life history, and memory of biotic/abiotic stresses.Medicago truncatula growth and endophytic fungi are affected by neighboring plants and by plants from the previous season. Thus, both intercropping and crop rotation affect the ecological performance of alfalfa as the holobiome (Vannier et al. , 2020). Rotation in hydroponic systems also affects the next crop's performance. Vicia faba plants infested by Acyrthosiphon pisum release soluble chemicals that increase the attractiveness of the next plant parasitoid Aphidius ervi . Similarly, lima bean infested by Tetranychus urticae increase the next season plant's attraction of the predatory mite Phytoseiulus persimilis (Delory et al. , 2016, Guerrieri, Dong \& Bouwmeester, 2019).

Large-scale formulation and application of inter-plant infochemicals is a promising approach in integrated crop management. These compounds can be considered as synthetic pesticide alternatives and can reduce their application dose by combining synthetic pesticides and pest lure volatiles to attract and kill pest (Martel, Alford \& Dickens, 2007). However, infochemicals are highly reactive compounds with short halflives under natural conditions. Plant should be treated with these compounds at the proper time under optimum conditions to avoid neutral or negative effects on plant growth and defense. Micro- and nanoencapsulation of infochemicals in natural and synthetic polymers for slow- or controlled-release improves their effects on plant health and volatile emission (Oliveira, Varanda \& Félix, 2016, Wang, Liu, Zhan \& Liu, 2019). Plant virus particles can be used to deliver infochemicals into the rhizosphere (Chariou, Dogan, Welsh, Saidel, Baskaran \& Steinmetz, 2019). The formulation technologies and field applications of infochemicals is 
reviewed elsewhere (Sharifi \& Ryu, 2018a, Sharifi \& Ryu, 2020).

\section{4 ? CONCLUDING REMARKS}

The holobiont is an evolutionary collaboration that assembles individual species with unique contributions that benefit all members and enhance holobiont performance and survival. Plant members of the holobiome compete with kin and non-kin plants for light, water, and nutrients (Ballare \& Austin, 2019, Effah, Holopainen \& McCormick, 2019, Hodge, Fitter \& Robinson, 2013, Hortal et al. , 2017). However, only some of the competition mechanisms rely on the plant genome. Plant microbiota have pivotal roles in nutrient solubility and uptake, especially nitrogen, phosphorus, and iron (Adesemoye, Torbert \& Kloepper, 2008, Sharifi, Ahmadzadeh, Sharifi-Tehrani \& Talebi-Jahromi, 2010). Microbiota also improve water use efficiency and osmotic stress response (Fan, Hu, Huang, Huang, Li \& Palta, 2015, Sharifi \& Ryu, 2018c). The plant holobiome leverages the collection of its member genes to optimize performance and survival. Plant health also depends on the hologenome. Plants have spatiotemporal layers of defense consisting of rhizosphere microbes, endophytes, PTI, ETI, and recruited natural enemies; each of these can efficiently suppress specific groups of attackers (Carrion et al. , 2019, Sharifi \& Ryu, 2017). Because of these advantages conferred by microbiota, plants donate $10-30 \%$ of their carbon and nitrogen to the rhizosphere to organize their microbiota. Mycorrhizae are long-term plant partners that can expand the rhizosphere into an area called the mycorrhizosphere. Microbes also manage their rhizosphere conditions by modulating mycorrhizae growth and inducing root metabolism and exudation (Korenblum et al. , 2020).

In competitive environments, plant species dominance partly depends on the microbiome. The microbiome of dominant plants is more stable during competition, and the soil microbiome resulting from plant competition is shaped by the dominant plant species (Hortal et al. , 2017). Dominant plants may have an intrinsic ability to collaborate with beneficial microbiota to enhance competitiveness. For example,Lycium intricatum exploits Halomonas andSalinimicrobium genera in water-competitive environments (Hortalet al. , 2017).

Domestication, plant breeding, and agricultural practices change the intrinsic ability of plants to establish diverse highly functional microbiota (Hassani, Duran \& Hacquard, 2018, Martinez-Romero, Noyola, Taype, Martinez-Romero \& Davila, 2020, Wang et al. , 2020b). Key metabolites or sensory proteins may be lost during domestication, resulting in the loss of groups of microbiota or of the ability to recruit natural enemies (Kollner, Held, Lenk, Hiltpold, Turlings, Gershenzon \& Degenhardt, 2008, Martinez-Romero et al. , 2020). Therefore, plant breeders and genetic engineers should have a holistic view of plants as members of the holobiome. Otherwise, small changes in key ecology-related genes may substantially affect plant performance, a phenomenon called the butterfly effect.

\section{ACKNOWLEDGMENTS}

We appreciate Ms. Meeae Hwang and Hanhee Na for drawing Figure 1. This research was supported by grants from the BioNano Health-Guard Research Center funded by the Ministry of Science, ICT, and Future Planning of Korea as a Global Frontier Project (Grant H-GUARD_2013M3A6B2078953), the Strategic Initiative for Microbiomes in Agriculture and Food, Ministry of Agriculture, Food and Rural Affairs, Republic of Korea [as part of the (multiministerial) Genome Technology to Business Translation Program 918017-4], and the KRIBB Initiative Program, South Korea.

\section{CONFLICT OF INTEREST}

The authors declare no conflicts of interest.

Table 1. Effect of plant-plant communication via volatile organic compounds and root exudates on the suppression of plant pathogens.

\begin{tabular}{lllll}
\hline Donor plant & Receiver plant & Signal molecule & $\begin{array}{l}\text { Target } \\
\text { pathogen }\end{array}$ & Reference \\
\hline $\begin{array}{l}\text { Volatile organic } \\
\text { compounds }\end{array}$ & $\begin{array}{l}\text { Volatile organic } \\
\text { compounds }\end{array}$ & & &
\end{tabular}




\begin{tabular}{|c|c|c|c|c|}
\hline Donor plant & Receiver plant & Signal molecule & $\begin{array}{l}\text { Target } \\
\text { pathogen }\end{array}$ & Reference \\
\hline Lima bean & Lima bean & VOC, nonanal & $\begin{array}{l}\text { Pseudomonas } \\
\text { syringae pv. } \\
\text { syringae PR-2 }\end{array}$ & (Yi et al., 2009) \\
\hline Tomato & Tomato & $\begin{array}{l}(Z) \text {-3-hexenyl } \\
\text { propionate } \\
(Z) \text {-3-hexenyl } \\
\text { butyrate }\end{array}$ & $\begin{array}{l}\text { Pseudomonas } \\
\text { syringae pv. tomato } \\
\text { stomatal closure }\end{array}$ & $\begin{array}{l}\text { (Lopez-Gresa, Paya, } \\
\text { Ozaez, Rodrigo, } \\
\text { Conejero, Klee, } \\
\text { Belles \& Lison, } \\
2018 \text { ) }\end{array}$ \\
\hline Maize & Maize & $\begin{array}{l}(Z)-3 \text {-hexen-1-yl } \\
\text { acetate, } \\
(Z)-3 \text {-hexenal, } \\
\text { linalool and } \\
\beta \text {-caryophyllene }\end{array}$ & Fusarium spp. & $\begin{array}{l}\text { (Piesik, } \\
\text { Lemnczyk, } \\
\text { Skoczek, } \\
\text { Lamparski, } \\
\text { Bocianowski, } \\
\text { Kotwica \& } \\
\text { Delaney, 2011) }\end{array}$ \\
\hline Barley and wheat & Barley and wheat & $\begin{array}{l}\text { GLV, } \\
(Z) \text {-b-ocimene } \\
\text { and linalool }\end{array}$ & Fusarium spp. & $\begin{array}{l}\text { (Piesik et al., } \\
\text { 2013) }\end{array}$ \\
\hline Wheat & Wheat & $\begin{array}{l}\text { GLVs, fatty acid } \\
\text { derivatives, } \\
\text { benzenoids, and } \\
\text { terpenoid }\end{array}$ & Puccinia triticina & $\begin{array}{l}\text { (Castelyn et al., } \\
\text { 2014) }\end{array}$ \\
\hline Lima bean & Lima bean & $\begin{array}{l}\text { Limonene, } \\
\text { linalool, nonanal, } \\
\text { methyl salicylate, } \\
\text { and methyl } \\
\text { jasmonate }\end{array}$ & $\begin{array}{l}\text { Colletortichum } \\
\text { lindemuthianum }\end{array}$ & $\begin{array}{l}\text { (Quintana- } \\
\text { Rodriguez et al., } \\
\text { 2015) }\end{array}$ \\
\hline Tobacco & Tobacco & Methyl salicylate & $\begin{array}{l}\text { Tobacco mosaic } \\
\text { virus (TMV) }\end{array}$ & $\begin{array}{l}\text { (Shulaev, } \\
\text { Silverman \& } \\
\text { Raskin, 1997) }\end{array}$ \\
\hline $\begin{array}{l}\text { Tea (Camellia } \\
\text { sinensis) }\end{array}$ & Tea & $(E)$-nerolidol & $\begin{array}{l}\text { Colletotrichum } \\
\text { fructicola }\end{array}$ & $\begin{array}{l}\text { (Chen, Zhang, } \\
\text { Cai, Li, Bian, } \\
\text { Luo, Li, Chen \& } \\
\text { Xin, 2020) }\end{array}$ \\
\hline $\begin{array}{l}\text { Arabidopsis } \\
\text { thaliana }\end{array}$ & A. thaliana & $\alpha$ - and $\beta$-pinene & $\begin{array}{l}\text { P. syringae pv. } \\
\text { tomato }\end{array}$ & $\begin{array}{l}\text { (Riedlmeier, } \\
\text { Ghirardo, Wenig, } \\
\text { Knappe, Koch, } \\
\text { Georgii, Dey, } \\
\text { Parker, Schnitzler } \\
\text { \& Vlot, 2017) }\end{array}$ \\
\hline Maize & Maize & $\begin{array}{l}\text { GLVs, terpenes } \\
\text { Shikimic acid } \\
\text { pathway derivatives }\end{array}$ & Pantoea ananatis & $\begin{array}{l}\text { (Delaney, } \\
\text { Breza-Boruta, } \\
\text { Lemańczyk, } \\
\text { Bocianowski, } \\
\text { Wrzesińska, Kalka } \\
\text { \& Piesik, 2015) }\end{array}$ \\
\hline
\end{tabular}

\section{Root exudates}




\begin{tabular}{|c|c|c|c|c|}
\hline Donor plant & Receiver plant & Signal molecule & $\begin{array}{l}\text { Target } \\
\text { pathogen }\end{array}$ & Reference \\
\hline $\begin{array}{l}\text { Poncirus } \\
\text { trifoliata }\end{array}$ & P. trifoliata & $\begin{array}{l}\text { Salicylic acid } \\
(\mathrm{SA})\end{array}$ & $\begin{array}{l}\text { Xanthomonas } \\
\text { axonopodis pv. } \\
\text { citri }\end{array}$ & $\begin{array}{l}\text { (Zhang, Zou, Liu } \\
\text { \& Wu, 2019) }\end{array}$ \\
\hline Maize & Pepper & $\begin{array}{l}2,4 \text {-Dihydroxy-7- } \\
\text { methoxy-2H-1,4- } \\
\text { benzoxazin-3(4H)- } \\
\text { one, } \\
6 \text {-methoxy-2- } \\
\text { benzoxazolinone, } \\
\text { benzothiazole, and } \\
2 \text {-(methylthio)- } \\
\text { benzothiazole }\end{array}$ & $\begin{array}{l}\text { Phytophthora } \\
\text { capsici }\end{array}$ & (Yang et al., 2014) \\
\hline Tobacco & Tobacco & $\mathrm{SA}$ & $\begin{array}{l}\text { Ralstonia } \\
\text { solanacearum and } \\
\text { P. syringae pv. } \\
\text { tabaci }\end{array}$ & $\begin{array}{l}\text { (Cheol Song, Sim, } \\
\text { Kim \& Ryu, } \\
2016)\end{array}$ \\
\hline Arabidopsis thaliana & A. thaliana & $\begin{array}{l}\text { Root-derived } \\
\text { signal(s) }\end{array}$ & $\begin{array}{l}\text { Pseudomonas } \\
\text { syringae pv. tomato }\end{array}$ & $\begin{array}{l}\text { (Orlovskis \& } \\
\text { Reymond, 2020) }\end{array}$ \\
\hline
\end{tabular}

Reference

Adesemoye A.O., Torbert H.A. \& Kloepper J.W. (2008) Enhanced plant nutrient use efficiency with PGPR and AMF in an integrated nutrient management system. Can J Microbiol , 54, 876-886.

Alborn H., Turlings T., Jones T.H., Stenhagen G., Loughrin J. \& Tumlinson J. (1997) An elicitor of plant volatiles from beet armyworm oral secretion. Science, $\mathbf{2 7 6}, 945-949$.

Alborn H.T., Hansen T.V., Jones T.H., Bennett D.C., Tumlinson J.H., Schmelz E.A. \& Teal P.E. (2007) Disulfooxy fatty acids from the American bird grasshopper Schistocerca americana, elicitors of plant volatiles. Proceedings of the National Academy of Sciences ,104, 12976-12981.

Ali J.G., Alborn H.T. \& Stelinski L.L. (2011) Constitutive and induced subterranean plant volatiles attract both entomopathogenic and plant parasitic nematodes. Journal of Ecology , 99 , 26-35.

Ameye M., Allmann S., Verwaeren J., Smagghe G., Haesaert G., Schuurink R.C. \& Audenaert K. (2018) Green leaf volatile production by plants: a meta-analysis. New Phytologist, 220 , 666-683.

Ameye M., Audenaert K., De Zutter N., Steppe K., Van Meulebroek L., Vanhaecke L., De Vleesschauwer D., Haesaert G. \& Smagghe G. (2015) Priming of wheat with the green leaf volatile Z-3-hexenyl acetate enhances defense against Fusarium graminearum but boosts deoxynivalenol production. Plant physiology, 167, 1671-1684.

Andika I.B., Wei S., Cao C., Salaipeth L., Kondo H. \& Sun L. (2017) Phytopathogenic fungus hosts a plant virus: A naturally occurring cross-kingdom viral infection. Proceedings of the National Academy of Sciences , $114,12267-12272$.

Babikova Z., Gilbert L., Bruce T.J., Birkett M., Caulfield J.C., Woodcock C., Pickett J.A. \& Johnson D. (2013) Underground signals carried through common mycelial networks warn neighbouring plants of aphid attack. Ecology Letters, 16 , 835-843.

Bailly A., Groenhagen U., Schulz S., Geisler M., Eberl L. \& Weisskopf L. (2014) The inter-kingdom volatile signal indole promotes root development by interfering with auxin signalling. Plant $J$,80 , 758-771. 
Ballaré C.L. \& Austin A.T. (2019) Recalculating growth and defense strategies under competition: key roles of photoreceptors and jasmonates. Journal of Experimental Botany , 70 , 3425-3436.

Barto E.K., Hilker M., Muller F., Mohney B.K., Weidenhamer J.D. \& Rillig M.C. (2011) The fungal fast lane: common mycorrhizal networks extend bioactive zones of allelochemicals in soils. PLoS One ,6, e27195.

Bell K., Naranjo-Guevara N., Santos R.C., Meadow R. \& Bento J.M.S. (2020) Predatory earwigs are attracted by herbivore-induced plant volatiles linked with plant growth-promoting rhizobacteria.Insects of Jianfengling , $11,217$.

Bennett J.A., Cahill J.F. \& van der Heijden M. (2016) Fungal effects on plant-plant interactions contribute to grassland plant abundances: evidence from the field. Journal of Ecology , 104 , 755-764.

Berg G., Rybakova D., Fischer D., Cernava T., Vergès M.-C.C., Charles T., Chen X., Cocolin L., Eversole K. \& Corral G.H. (2020) Microbiome definition re-visited: old concepts and new challenges.Microbiome , 8 , $1-22$.

Bian R., Andika I.B., Pang T., Lian Z., Wei S., Niu E., Wu Y., Kondo H., Liu X. \& Sun L. (2020) Facilitative and synergistic interactions between fungal and plant viruses. Proceedings of the National Academy of Sciences, 117 , 3779-3788.

Bichlmeier M. (2017) Identification of Systemic Acquired Resistance-Related Volatile Organic Compounds and their Role in Plant Immunity, Technische Universität München.

Bittebiere A.-K., Benot M.-L. \& Mony C. (2020) Clonality as a key but overlooked driver of biotic interactions in plants. Perspectives in Plant Ecology, Evolution and Systematics , 43, 125510.

Body M.J.A., Neer W.C., C. V., Lin C.-H., Vu D. \& Cocroft R.B. (2019) Caterpillar chewing vibrations cause changes in plant hormones and volatile emissions in Arabidopsis thaliana. Frontiers in Plant Science , 10:810 .

Bonaventure G., VanDoorn A. \& Baldwin I.T. (2011) Herbivore-associated elicitors: FAC signaling and metabolism. Trends in Plant Science ,16 , 294-299.

Bouwmeester H., Schuurink R.C., Bleeker P.M. \& Schiestl F. (2019) The role of volatiles in plant communication. Plant Journal ,100, 892-907.

Caicedo-Lopez L.H., Contreras-Medina L.M., Guevara-Gonzaleza R.G., Perez-Matzumotob A.E. \& RuizRuedab A. (2020) Effects of hydric stress on vibrational frequency patterns of Capsicum annuum plants. Plant Signaling Behavior, e1770489-2 .

Camacho-Coronel X., Molina-Torres J. \& Heil M. (2020) Sequestration of exogenous volatiles by plant cuticular waxes as a mechanism of passive associational resistance: a proof of concept. Frontiers in Plant Science, $\mathbf{1 1}, 121$.

Carrión V.J., Perez-Jaramillo J., Cordovez V., Tracanna V., de Hollander M., Ruiz-Buck D., Mendes L.W., van Ijcken V.F.J., Medema M.H. \& Raaijmakers J. (2019) Pathogen-induced activation of disease-suppressive functions in the endophytic root microbiome. Science ,366 , 606-612.

Carvalhais L.C., Dennis P.G., Badri D.V., Kidd B.N., Vivanco J.M. \& Schenk P.M. (2015) Linking jasmonic acid signaling, root exudates, and rhizosphere microbiomes. Molecular Plant Microbe Interactions ,28 , 1049-1058.

Carvalhais L.C., Rincon-Florez V.A., Brewer P.B., Beveridge C.A., Dennis P.G. \& Schenk P.M. (2019) The ability of plants to produce strigolactones affects rhizosphere community composition of fungi but not bacteria. Rhizosphere, $\mathbf{9}, 18-26$.

Castelyn H.D., Appelgryn J.J., Mafa M.S., Pretorius Z.A. \& Visser B. (2014) Volatiles emitted by leaf rust infected wheat induce a defence response in exposed uninfected wheat seedlings. Australasian Plant Pathology 
, $44,245-254$.

Chalal M., Winkler J.B., Gourrat K., Trouvelot S., Adrian M., Schnitzler J.-P., Jamois F. \& Daire X. (2015) Sesquiterpene volatile organic compounds (VOCs) are markers of elicitation by sulfated laminarine in grapevine. Frontiers in plant science , 6 , 350. doi: 310.3389/fpls.2015.00350.

Chang C., Kwok S.F., Bleecker A.B. \& Meyerowitz E.M. (1993) Arabidopsis ethylene-response gene ETR1: similarity of product to two-component regulators. Science, 262, 539-544.

Chariou P.L., Dogan A.B., Welsh A.G., Saidel G.M., Baskaran H. \& Steinmetz N.F. (2019) Soil mobility of synthetic and virus-based model nanopesticides. Nature Nanotechnology , 14 , 712-718.

Chen B.J., During H.J. \& Anten N.P. (2012) Detect thy neighbor: identity recognition at the root level in plants. Plant Science ,195 , 157-167.

Chen H., Yang R., Chen J., Luo Q., Cui X., Yan X. \& Gerwick W.H. (2019a) 1-Octen-3-ol, a self-stimulating oxylipin messenger, can prime and induce defense of marine alga. BMC Plant Biology ,19, 37.

Chen Q., Jiang T., Liu Y.X., Liu H., Zhao T., Liu Z., Gan X., Hallab A., Wang X., He J., Ma Y., Zhang F., Jin T., Schranz M.E., Wang Y., Bai Y. \& Wang G. (2019b) Recently duplicated sesterterpene (C25) gene clusters in Arabidopsis thaliana modulate root microbiota. Sci China Life Sci , 62 , 947-958.

Chen S., Zhang L., Cai X., Li X., Bian L., Luo Z., Li Z., Chen Z. \& Xin Z. (2020) (E)-Nerolidol is a volatile signal that induces defenses against insects and pathogens in tea plants. Hortic Res ,7 , 52.

Cheol Song G., Sim H.-J., Kim S.-G. \& Ryu C.-M. (2016) Root-mediated signal transmission of systemic acquired resistance against above-ground and below-ground pathogens. Annals of botany , 118, 821-831.

Chiriboga X., Guo H., Campos-Herrera R., Röder G., Imperiali N., Keel C., Maurhofer M. \& Turlings T.C. (2018) Root-colonizing bacteria enhance the levels of (E)- $\beta$-caryophyllene produced by maize roots in response to rootworm feeding. Oecologia , 187, 459-468.

Choi W.-G., Miller G., Wallace I., Harper J., Mittler R. \& Gilroy S. (2017) Orchestrating rapid long-distance signaling in plants with Ca2+, ROS and electrical signals. The Plant Journal , 90 , 698-707.

Cipollini D., Rigsby C.M. \& Barto E.K. (2012) Microbes as targets and mediators of allelopathy in plants. Journal of Chemical Ecology ,38, 714-727.

Conrath U., Beckers G.J., Langenbach C.J. \& Jaskiewicz M.R. (2015) Priming for enhanced defense. Annu Rev Phytopathol, 53, 97-119.

Copolovici L., Kannaste A., Pazouki L. \& Niinemets U. (2012) Emissions of green leaf volatiles and terpenoids from Solanum lycopersicumare quantitatively related to the severity of cold and heat shock treatments. Journal of Plant Physiology, 169, 664-672.

Cotton T.E.A., Petriacq P., Cameron D.D., Meselmani M.A., Schwarzenbacher R., Rolfe S.A. \& Ton J. (2019) Metabolic regulation of the maize rhizobiome by benzoxazinoids. ISME Journal ,13 , 1647-1658.

D’Alessandro M., Erb M., Ton J., Brandenburg A., Karlen D., Zopfi J. \& Turlings T.C. (2014) Volatiles produced by soil-borne endophytic bacteria increase plant pathogen resistance and affect tritrophic interactions. Plant, cell \& environment, 37, 813-826.

da Trindade R., Almeida L., Xavier L., Lins A.L., Andrade E.H., Maia J.G., Mello A., Setzer W.N., Ramos A. \& da Silva J.K. (2019) Arbuscular mycorrhizal fungi colonization promotes changes in the volatile compounds and enzymatic activity of lipoxygenase and phenylalanine ammonia lyase in Piper nigrum L. 'Bragantina'. Plants (Basel), 8 .

De Lange E.S., Laplanche D., Guo H., Xu W., Vlimant M., Erb M., Ton J. \& Turlings T.C. (2020) Spodoptera frugiperda caterpillars suppress herbivore-induced volatile emissions in Maize. Journal of Chemical Ecology , $1-17$. 
de Toledo G.R.A., Parise A.G., Simmi F.Z., Costa A.V.L., Senko L.G.S., Debono M.-W. \& Souza G.M. (2019) Plant electrome: the electrical dimension of plant life. Theoretical and Experimental Plant Physiology , 31, 21-46.

Deja-Sikora E., Mercy L., Baum C. \& Hrynkiewicz K. (2019) The Contribution of endomycorrhiza to the performance of potato virus y-infected solanaceous plants: disease alleviation or exacerbation? Frontiers in Microbiology, $\mathbf{1 0}, 516$.

Delaney K.J., Breza-Boruta B., Lemańczyk G., Bocianowski J., Wrzesińska D., Kalka I. \& Piesik D. (2015) Maize VOC induction after infection by the bacterial pathogen, Pantoea ananatis, alters neighbouring plant VOC emissions. Journal of Plant Diseases and Protection ,122, 125-132.

Delory B.M., Delaplace P., Fauconnier M.-L. \& du Jardin P. (2016) Root-emitted volatile organic compounds: can they mediate belowground plant-plant interactions? Plant and Soil , 402 , 1-26.

Desurmont G.A., Xu H. \& Turlings T.C. (2016) Powdery mildew suppresses herbivore-induced plant volatiles and interferes with parasitoid attraction in Brassica rapa. Plant, Cell $\& 3$ Environment ,39, 1920-1927.

Dini-Andreote F. (2020) Endophytes: the second layer of plant defense. Trends in Plant Science.

Disi J.O., Mohammad H.K., Lawrence K., Kloepper J. \& Fadamiro H. (2019) A soil bacterium can shape belowground interactions between maize, herbivores and entomopathogenic nematodes. Plant and Soil ,437 , 83-92.

Dombrowski J.E., Kronmiller B.A., Hollenbeck V.G., Rhodes A.C., Henning J.A. \& Martin R.C. (2019) Transcriptome analysis of the model grassLolium temulentum exposed to green leaf volatiles. BMC Plant Biology , 19 , 222.

Dombrowski J.E. \& Martin R.C. (2018) Activation of MAP kinases by green leaf volatiles in grasses. $B M C$ Research Notes, $11,1-6$.

Eberl F., Hammerbacher A., Gershenzon J. \& Unsicker S.B. (2018) Leaf rust infection reduces herbivoreinduced volatile emission in black poplar and attracts a generalist herbivore. New Phytologist ,220 , 760-772.

Edwards J.A., Santos-Medellın C.M., Liechty Z.S., Nguyen B., Lurie E. \& Eason S. (2018) Compositional shifts in root-associated bacterial and archaeal microbiota track the plant life cycle in field-grown rice.PLoS Biology, 16(2): e2003862 .

Effah E., Holopainen J.K. \& McCormick A.C. (2019) Potential roles of volatile organic compounds in plant competition. Perspectives in Plant Ecology, Evolution and Systematics , 38 , 58-63.

Erb M., Veyrat N., Robert C.A., Xu H., Frey M., Ton J. \& Turlings T.C. (2015) Indole is an essential herbivore-induced volatile priming signal in maize. Nature communications , 6 , 1-10.

Falik O., Mordoch Y., Ben-Natan D., Vanunu M., Goldstein O. \& Novoplansky A. (2012) Plant responsiveness to root-root communication of stress cues. Annals of Botany, 110, 271-280.

Fan X., Hu H., Huang G., Huang F., Li Y. \& Palta J. (2015) Soil inoculation with Burkholderia sp. LD-11 has positive effect on water-use efficiency in inbred lines of maize. Plant and Soil ,390 , 337-349.

Ghosh R., Mishra R.C., Choi B., Kwon Y.S., Won Bae D., Park S.C.J., M.J. \& Bae H. (2016) Exposure to sound vibrations lead to transcriptomic, proteomic and hormonal changes in arabidopsis. Scientific Report ,6, 33370 .

Gilbert L. \& Johnson D. (2017) Plant-plant communication through common mycorrhizal networks. In: Advances in Botanical Research, pp. 83-97. Elsevier.

Gilbert S.F. (2019) Evolutionary transitions revisited: Holobiont evo-devo. Journal of Experimental Zoology $332,307-314$. 
Glazebrook J. (2005) Contrasting mechanisms of defense against biotrophic and necrotrophic pathogens. Annual Reveiw of Phytopathology , 43, 205-227.

Gómez S. \& Stuefer J.F. (2006) Members only: induced systemic resistance to herbivory in a clonal plant network. Oecologia ,147, 461-468.

Gómez S., Van Dijk W. \& Stuefer J.F. (2010) Timing of induced resistance in a clonal plant network. Plant Biology , 12, 512-517.

Gorman Z., Christensen S.A., Yan Y., He Y., Borrego E. \& Kolomiets M.V. (2020) Green leaf volatiles and jasmonic acid enhance susceptibility to anthracnose diseases caused by Colletotrichum graminicola in maize. Molecular Plant Pathology, 21, 702-715.

Gu Y., Wei Z., Wang X., Friman V.-P., Huang J., Wang X., Mei X., Xu Y., Shen Q. \& Jousset A. (2016) Pathogen invasion indirectly changes the composition of soil microbiome via shifts in root exudation profile.Biology and Fertility of Soils , 52, 997-1005.

Guerrieri A., Dong L. \& Bouwmeester H.J. (2019) Role and exploitation of underground chemical signaling in plants. Pest Management Science, 75, 2455-2463.

Hassani M.A., Duran P. \& Hacquard S. (2018) Microbial interactions within the plant holobiont. Microbiome $, 6,58$.

Heil M. \& Bueno J.C.S. (2014) Herbivore-Induced Volatiles as Rapid Signals in Systemic Plant Responses. Plant Signal. Behav. ,2, 191-193.

Hettenhausen C., Li J., Zhuang H., Sun H., Xu Y., Qi J., Zhang J., Lei Y., Qin Y., Sun G., Wang L., Baldwin I.T. \& Wu J. (2017) Stem parasitic plant Cuscuta australis (dodder) transfers herbivory-induced signals among plants. Proceedings of the National Academy of Sciences ,114, E6703-E6709.

Hodge A., Fitter A.H. \& Robinson D. (2013) Microbial mediation of plant competition and community structure. Functional Ecology ,27, 865-875.

Hopke J., Donath J., Blechert S. \& Boland W. (1994) Herbivore-induced volatiles: the emission of acyclic homoterpenes from leaves of Phaseolus lunatus and Zea mays can be triggered by a $\beta$-glucosidase and jasmonic acid. Febs Letters , 352, 146-150.

Hortal S., Lozano Y.M., Bastida F., Armas C., Moreno J.L., Garcia C. \& Pugnaire F.I. (2017) Plant-plant competition outcomes are modulated by plant effects on the soil bacterial community. Scientific Report ,7 , 17756 .

Hu L., Ye M. \& Erb M. (2019) Integration of two herbivore-induced plant volatiles results in synergistic effects on plant defence and resistance. Plant, Cell \& Environment , 42 , 959-971.

Huang M., Sanchez-Moreiras A.M., Abel C., Sohrabi R., Lee S., Gershenzon J. \& Tholl D. (2012) The major volatile organic compound emitted fromArabidopsis thaliana flowers, the sesquiterpene (E)-betacaryophyllene, is a defense against a bacterial pathogen. New Phytologist , 193 , 997-1008.

Jassbi A.R., Zamanizadehnajari S. \& Baldwin I.T. (2010) Phytotoxic volatiles in the roots and shoots of Artemisia tridentata as detected by headspace solid-phase microextraction and gas chromatographic-mass spectrometry analysis. Journal of Chemical Ecology , 36 , 1398-1407.

Jia Q., Kollner T.G., Gershenzon J. \& Chen F. (2018) MTPSLs: New Terpene Synthases in Nonseed Plants. Trends Plant Sci ,23, 121-128.

Jiang Y., Ye J., Veromann L.-L. \& Niinemets Ü. (2016) Scaling of photosynthesis and constitutive and induced volatile emissions with severity of leaf infection by rust fungus (Melampsora larici-populina) in Populus balsamifera var. suaveolens .Tree Physiology, 1-17. 
Jung H.W., Tschaplinski T.J., Wang L., Glazebrook J. \& Greenberg J.T. (2009) Priming in systemic plant immunity. Science $\mathbf{3 2 4}$, 89-91.

Jung J., Kim S.-K., Jung S.-H., Jeong M.-J. \& Ryu C.-M. (2020) Sound vibration-triggered epigenetic modulation induces plant root immunity against Ralstonia solanacearum . Frontiers in Microbiology ,11, 1978. doi: $1910.3389 /$ fmicb.2020.01978.

Karamanoli K., Kokalas V., Koveos D., Junker R. \& Farré-Armengol G. (2020) Bacteria affect plant-mite interactions via altered scent emissions. Journal of Chemical Ecology, 1-11.

Karban R. \& Shiojiri K. (2009) Self-recognition affects plant communication and defense. Ecology Letters, $12,502-506$.

Karban R., Shiojiri K., Ishizaki S., Wetzel W.C. \& Evans R.Y. (2013) Kin recognition affects plant communication and defence. P Roy Soc B-Biol Sci , 280, 20123062.

Karban R., Wetzel W.C., Shiojiri K., Ishizaki S., Ramirez S.R. \& Blande J.D. (2014) Deciphering the language of plant communication: volatile chemotypes of sagebrush. New Phytol , 204 , 380-385.

Kessler A. \& Heil M. (2011) The multiple faces of indirect defences and their agents of natural selection. Functional Ecology ,25, 348-357.

Klimm F.S., Weinhold A. \& Volf M. (2020) Volatile production differs between oak leaves infested by leafminer Phyllonorycter harrisella (Lepidoptera: Gracillariidae) and galler Neuroterus quercusbaccarum (Hymenoptera: Cynipidae). European Journal of Entomology , 117, 101-109.

Kollasch A.M., Abdul-Kaf A., Body M.J.A., Pinto C.F., Appel H.M. \& Cocroft R.B. (2020) Leaf vibrations produced by chewing provide a consistent acoustic target for plant recognition of herbivores. Oecologia .

Kollner T.G., Held M., Lenk C., Hiltpold I., Turlings T.C.J., Gershenzon J. \& Degenhardt J. (2008) A maize (E)- $\beta$-caryophyllene synthase implicated in indirect defense responses against herbivores is not expressed in most american maize varieties. The Plant Cell ,20 , 482-494.

Kong C.H., Zhang S.Z., Li Y.H., Xia Z.C., Yang X.F., Meiners S.J. \& Wang P. (2018) Plant neighbor detection and allelochemical response are driven by root-secreted signaling chemicals. Nature Communications, $\mathbf{9}, 3867$.

Kong H.G., Song G.C., Sim H.J. \& Ryu C.-M. (2020) Achieving similar root microbiota composition in neighbouring plants through airborne signalling. ISME Journal, In Press .

Korenblum E., Dong Y., Szymanski J., Panda S., Jozwiak A., Massalha H., Meir S., Rogachev I. \& Aharoni A. (2020) Rhizosphere microbiome mediates systemic root metabolite exudation by root-to-root signaling.Proceedings of the National Academy of Sciences , 117, 3874-3883.

Kroes A., Weldegergis B.T., Cappai F., Dicke M. \& van Loon J.J. (2017) Terpenoid biosynthesis in Arabidopsis attacked by caterpillars and aphids: effects of aphid density on the attraction of a caterpillar parasitoid. Oecologia , 185, 699-712.

Kudjordjie E.N., Sapkota R., Steffensen S.K., Fomsgaard I.S. \& Nicolaisen M. (2019) Maize synthesized benzoxazinoids affect the host associated microbiome. Microbiome, 7,59 .

Kwon Y.S., Ryu C.M., Lee S., Park H.B., Han K.S., Lee J.H., Lee K., Chung W.S., Jeong M.J., Kim H.K. \& Bae D.W. (2010) Proteome analysis of Arabidopsis seedlings exposed to bacterial volatiles.Planta , 232, $1355-1370$.

Lazazzara V., Bueschl C., Parich A., Pertot I., Schuhmacher R. \& Perazzolli M. (2018) Downy mildew symptoms on grapevines can be reduced by volatile organic compounds of resistant genotypes. Scientific Reports , 8, 1618. 
Lazebnik J., Tibboel M., Dicke M. \& van Loon J.J. (2017) Inoculation of susceptible and resistant potato plants with the late blight pathogenPhytophthora infestans : effects on an aphid and its parasitoid.Entomologia Experimentalis et Applicata , 163, 305-314.

Lee B., Lee S. \& Ryu C.M. (2012) Foliar aphid feeding recruits rhizosphere bacteria and primes plant immunity against pathogenic and non-pathogenic bacteria in pepper. Annals of Botany ,110 , 281-290.

Lee S.M., Kim S.K., Lee N., Ahn C.Y. \& Ryu C.M. (2020) D-Lactic acid secreted by Chlorella fusca primes pattern-triggered immunity against Pseudomonas syringae in Arabidopsis. The Plant Journal , 102 , 761778 .

Leitner M., Kaiser R., Rasmussen M.O., Driguez H., Boland W. \& Mithöfer A. (2008) Microbial oligosaccharides differentially induce volatiles and signalling components in Medicago truncatula. Phytochemistry ,69 , 2029-2040.

Li S., Zhang J., Liu H., Liu N., Shen G., Zhuang H. \& Wu J. (2020) Dodder-transmitted mobile signals prime host plants for enhanced salt tolerance. Journal of Experimental Botany , 71 , 1171-1184.

Liang M., Johnson D., Burslem D., Yu S., Fang M., Taylor J.D., Taylor A.F.S., Helgason T. \& Liu X. (2020) Soil fungal networks maintain local dominance of ectomycorrhizal trees. Nature Communications ,11 , 2636.

Lin Y., Hussain M., Avery P.B., Qasim M., Fang D. \& Wang L. (2016) Volatiles from plants induced by multiple aphid attacks promote conidial performance of Lecanicillium lecanii . PLoS One ,11, e0151844.

Liu F., Rice J.H., Lopes V., Grewal P., Lebeis S.L., Hewezi T. \& Staton M.E. (2020) Overexpression of strigolactone-associated genes exerts fine-tuning selection on soybean rhizosphere bacterial and fungal microbiome. Phytobiomes Journal, PBIOMES-01-20-0003-R.

Lopez-Gresa M.P., Paya C., Ozaez M., Rodrigo I., Conejero V., Klee H., Belles J.M. \& Lison P. (2018) A New Role For Green Leaf Volatile Esters in Tomato Stomatal Defense Against Pseudomonas syringe pv. tomato.Front Plant Sci, $\mathbf{9}, 1855$.

Lopez-Raez J.A., Shirasu K. \& Foo E. (2017) Strigolactones in plant interactions with beneficial and detrimental organisms: the Yin and Yang. Trends in Plant Science, 22, 527-537.

Maggini V., Bandeira Reidel R.V., De Leo M., Mengoni A., Rosaria Gallo E., Miceli E., Biffi S., Fani R., Firenzuoli F., Bogani P. \& Pistelli L. (2020) Volatile profile of Echinacea purpurea plants after in vitro endophyte infection. Natural Product Research , 34, 2232-2237.

Mannaa M., Han G., Jeon H.W., Kim J., Kim N., Park A.R., Kim J.C. \& Seo Y.S. (2020) Influence of resistance-inducing chemical elicitors against pine wilt disease on the rhizosphere microbiome. Microorganisms , 8 .

Martel J.W., Alford A.R. \& Dickens J. (2007) Evaluation of a novel host plant volatile-based attracticide for management of Colorado potato beetle, Leptinotarsa decemlineata (Say). Crop Protection ,26 , 822-827.

Martínez-Romero E., Noyola J.L.A., Taype N.T., Martínez-Romero J. \& Dávila D.Z. (2020) Plant microbiota modified by plant domestication.Systematic and Applied Microbiology , 126106.

Min S., Chang-Qin Z., Yong-Peng M., Welti S., Moreau P.-A. \& Selosse M.-A. (2012) Mycorrhizal features and fungal partners of four mycoheterotrophic Monotropoideae (Ericaceae) species from Yunnan, China.Symbiosis , $\mathbf{5 7}, 1-13$.

Mirabella R., Rauwerda H., Allmann S., Scala A., Spyropoulou E.A., Vries M., Boersma M.R., Breit T.M., Haring M.A. \& Schuurink R.C. (2015) WRKY40 and WRKY6 act downstream of the green leaf volatile E-2-hexenal in Arabidopsis. The Plant Journal , 83 , 1082-1096.

Moisan K., Lucas-Barbosa D., Villela A., Greenberg L.O., Cordovez V., Raaijmakers J.M. \& Dicke M. No evidence of modulation of indirect plant resistance of Brassica rapa plants by volatiles from soil-borne fungi. 


\section{Ecological Entomology, $\mathbf{n} / \mathbf{a}$.}

Moreira X., Nell C.S., Katsanis A., Rasmann S. \& Mooney K.A. (2018) Herbivore specificity and the chemical basis of plant-plant communication in Baccharis salicifolia (Asteraceae). New Phytologist , 220 , 703-713.

Munoz-Parra E., Pelagio-Flores R., Raya-Gonzalez J., Salmeron-Barrera G., Ruiz-Herrera L.F., ValenciaCantero E. \& Lopez-Bucio J. (2017) Plant-plant interactions influence developmental phase transitions, grain productivity and root system architecture in Arabidopsis via auxin and PFT1/MED25 signalling. Plant, Cell \& Environment ,40, 1887-1899.

Neal A. \& Ton J. (2013) Systemic defense priming by Pseudomonas putida KT2440 in maize depends on benzoxazinoid exudation from the roots. Plant Signaling $\&$ Behavior , 8 , e22655.

Nerva L., Varese G.C., Falk B.W. \& Turina M. (2017) Mycoviruses of an endophytic fungus can replicate in plant cells: Evolutionary implications. Scientific Report, 7, 1908 .

Ninkovic V., Dahlin I., Vucetic A., Petrovic-Obradovic O., Glinwood R. \& Webster B. (2013) Volatile exchange between undamaged plants-a new mechanism affecting insect orientation in intercropping. PLoS One, 8 , e69431.

Okutani F., Hamamoto S., Aoki Y., Nakayasu M., Nihei N., Nishimura T., Yazaki K. \& Sugiyama A. (2020) Rhizosphere modeling reveals spatiotemporal distribution of daidzein shaping soybean rhizosphere bacterial community. Plant, Cell \& Environment, 43, 1036-1046.

Oliveira M.D.M., Varanda C.M.R. \& Felix M.R.F. (2016) Induced resistance during the interaction pathogen x plant and the use of resistance inducers. Phytochemistry Letters , 15 , 152-158.

Orlovskis Z. \& Reymond P. (2020) Pieris brassicae eggs trigger inter-plant systemic acquired resistance against a foliar pathogen inArabidopsis. New Phytologist .

Osmanovic D., Kessler D.A., Rabin Y. \& Soen Y. (2018) Darwinian selection of host and bacteria supports emergence of Lamarckian-like adaptation of the system as a whole. Biology Direct, 13 , 24.

Paika S.M., Jinb E.S., Simc S.J. \& N.L. J. (2018) Vibration-induced stress priming during seed culture increases microalgal biomass in high shear field-cultivation. Bioresource Technology .

Palmer A.G., Ali M., Yang S., Parchami N., Bento T., Mazzella A., Oni M., Riley M.C., Schneider K. \& Massa N. (2016) Kin recognition is a nutrient-dependent inducible phenomenon. Plant signaling $\&$ behavior , 11, e1224045.

Papale F., Saget J. \& Bapteste E. (2020) Networks consolidate the core concepts of evolution by natural selection. Trends in Microbiology, 28, 254-265.

Paschold A., Halitschke R. \& Baldwin I.T. (2006) Using 'mute' plants to translate volatile signals. Plant Journal , 45 , 275-291.

Penaflor M.F.G. \& Bento J.M.S. (2019) Red-rot infection in sugarcane attenuates the attractiveness of sugarcane borer-induced plant volatiles to parasitoid. Arthropod-Plant Interactions , 13 , 117-125.

Pickles B.J., Wilhelm R., Asay A.K., Hahn A.S., Simard S.W. \& Mohn W.W. (2017) Transfer of (13) C between paired Douglas-fir seedlings reveals plant kinship effects and uptake of exudates by ectomycorrhizas. New Phytologist, 214 , 400-411.

Pierik R., Visser E.J., de Kroon H. \& Voesenek L.A. (2003) Ethylene is required in tobacco to successfully compete with proximate neighbours. Plant, Cell 83 Environment, 26 , 1229-1234.

Piesik D., Lemnczyk G., Skoczek A., Lamparski R., Bocianowski J., Kotwica K. \& Delaney K.J. (2011) Fusarium infection in maize: volatile induction of infected and neighboring uninfected plants has the potential to attract a pest cereal leaf beetle, Oulema melanopus. Journal of Plant Physiology , 168 , 1534-1542. 
Piesik D., Pańka D., Jeske M., Wenda-Piesik A., Delaney K.J. \& Weaver D.K. (2013) Volatile induction of infected and neighbouring uninfected plants potentially influence attraction/repellence of a cereal herbivore. Journal of Applied Entomology , 137 , 296-309.

Pontin M., Bottini R., Burba J.L. \& Piccoli P. (2015) Allium sativum produces terpenes with fungistatic properties in response to infection with Sclerotium cepivorum . Phytochemistry ,115 , 152-160.

Poveda J., Hermosa R., Monte E. \& Nicolás C. (2019) Trichoderma harzianum favours the access of arbuscular mycorrhizal fungi to non-host Brassicaceae roots and increases plant productivity.Scientific Reports , $\mathbf{9}, 1-11$.

Qawasmeh A., Raman A. \& Wheatley W. (2015) Volatiles in perennial ryegrass infected with strains of endophytic fungus: impact on African black beetle host selection. Journal of Applied Entomology ,139 , 94-104.

Qian Y., Li D., Han L. \& Sun Z. (2010) Inter-ramet photosynthate translocation in buffalograss under differential water deficit stress. Journal of The American Society for Horticultural Science ,135 , 310-316.

Quintana-Rodriguez E., Morales-Vargas A.T., Molina-Torres J., Ádame-Alvarez R.M., Acosta-Gallegos J.A., Heil M. \& Flynn D. (2015) Plant volatiles cause direct, induced and associational resistance in common bean to the fungal pathogen Colletotrichum lindemuthianum. Journal of Ecology , 103 , 250-260.

Rasmann S., Kollner T.G., Degenhardt J., Hiltpold I., Toepfer S., Kuhlmann U., Gershenzon J. \& Turlings T.C.J. (2005) Recruitment of entomopathogenic nematodes by insect-damaged maize roots. Nature,434 , 732-737.

Ren L., Su S., Yang X., Xu Y., Huang Q. \& Shen Q. (2008) Intercropping with aerobic rice suppressed Fusarium wilt in watermelon. Soil Biology and Biochemistry, 40, 834-844.

Riedlmeier M., Ghirardo A., Wenig M., Knappe C., Koch K., Georgii E., Dey S., Parker J.E., Schnitzler J.P. \& Vlot A.C. (2017) Monoterpenes Support Systemic Acquired Resistance within and between Plants.Plant Cell , 29 , 1440-1459.

Rivas-San Vicente M. \& Plasencia J. (2011) Salicylic acid beyond defence: its role in plant growth and development. J Exp Bot ,62 , 3321-3338.

Robert C.A., Erb M., Duployer M., Zwahlen C., Doyen G.R. \& Turlings T.C. (2012) Herbivore-induced plant volatiles mediate host selection by a root herbivore. New Phytologist , 194 , 1061-1069.

Rodriguez P.A. \& Bos J.I. (2013) Toward understanding the role of aphid effectors in plant infestation. Molecular Plant-Microbe Interactions , 26 , 25-30.

Roiloa S.R., Antelo B. \& Retuerto R. (2014) Physiological integration modifies delta15N in the clonal plant Fragaria vesca, suggesting preferential transport of nitrogen to water-stressed offspring. Annals of Botany , $114,399-411$.

Roossinck M.J. (2019) Evolutionary and ecological links between plant and fungal viruses. New Phytologist , 221, 86-92.

Rudrappa T., Czymmek K.J., Pare P.W. \& Bais H.P. (2008) Root-secreted malic acid recruits beneficial soil bacteria. Plant Physiol ,148 , 1547-1556.

Runyon J.B., Mescher M.C. \& De Moraes C.M. (2010) Plant defenses against parasitic plants show similarities to those induced by herbivores and pathogens. Plant signaling $\& 3$ behavior ,5 , 929-931.

Rybakova D., Rack-Wetzlinger U., Cernava T., Schaefer A., Schmuck M. \& Berg G. (2017) Aerial warfare: a volatile dialogue between the plant pathogen Verticillium longisporum and its antagonistPaenibacillus polymyxa . Frontiers in plant science ,8 , 1294. doi: 1210.3389/fpls.2017.01294. 
Sanchez-Baracaldo P., Raven J.A., Pisani D. \& Knoll A.H. (2017) Early photosynthetic eukaryotes inhabited low-salinity habitats.Proceedings of the National Academy of Sciences , 114, E7737-E7745.

Semchenko M., John E.A. \& Hutchings M.J. (2007) Effects of physical connection and genetic identity of neighbouring ramets on root-placement patterns in two clonal species. New Phytol, 176 , 644-654.

Sharifi R., Ahmadzadeh M., Sharifi-Tehrani A. \& Talebi-Jahromi K. (2010) Pyoverdine production in Pseudomonas fluorescens UTPF5 and its association with suppression of common bean damping off caused byRhizoctonia solani (Kuhn). Journal of Plant Protection Research , 50 , 72-78.

Sharifi R., Lee S.M. \& Ryu C.M. (2018) Microbe-induced plant volatiles.New Phytologist, 220 , 684-691.

Sharifi R. \& Ryu C.-M. (2018a) Biogenic volatile compounds for plant disease diagnosis and health improvement. The Plant Pathology Journal, 34, 459-469.

Sharifi R. \& Ryu C.-M. (2018b) Revisiting bacterial volatile-mediated plant growth promotion: Lessons from the past and objectives for the future. Annals of Botany , 122, 349-358.

Sharifi R. \& Ryu C.-M. (2018c) Sniffing bacterial volatile compounds for healthier plants. Current Opinion In Plant Biology ,44, 88-97.

Sharifi R. \& Ryu C.-M. (2020) Formulation and Agricultural Application of Bacterial Volatile Compounds. In: Bacterial Volatile Compounds as Mediators of Airborne Interactions (ed C.-M.e.a. Ryu). Springer, Singapore.

Sharifi R. \& Ryu C.M. (2017) Chatting with a tiny belowground member of the holobiome: communication between plants and growth-promoting rhizobacteria. Advances in Botanical Research , 82 , 135-160.

Shulaev V., Silverman P. \& Raskin I. (1997) Airborne signalling by methyl salicylate in plant pathogen resistance. Nature ,385, 718-721.

Simard S.W. (2018) Mycorrhizal Networks Facilitate Tree Communication, Learning, and Memory. In: Memory and Learning in Plants, Signaling and Communication in Plants (ed F. Baluska), pp. 191-213. Springer.

Simmi F.Z., Dallagnol L.J., Ferreira A.S., Pereira D.R. \& Souza G.M. (2020) Electrome alterations in a plant-pathogen system: Toward early diagnosis. Bioelectrochemistry, 133 , 107493.

Sobhy I.S., Bruce T.J. \& Turlings T.C. (2018) Priming of cowpea volatile emissions with defense inducers enhances the plant's attractiveness to parasitoids when attacked by caterpillars. Pest Management Science , 74, 966-977.

Song G.C., Choi H.K. \& Ryu C.-M. (2015) Gaseous 3-pentanol primes plant immunity against a bacterial speck pathogen, Pseudomonas syringaepv. tomato via salicylic acid and jasmonic acid-dependent signaling pathways in Arabidopsis . Frontiers in Plant Science, $\mathbf{6}$.

Song G.C., Sim H.J., Kim S.G. \& Ryu C.M. (2016) Root-mediated signal transmission of systemic acquired resistance against above-ground and below-ground pathogens. Ann Bot .

Song Y.Y., Ye M., Li C., He X., Zhu-Salzman K., Wang R.L., Su Y.J., Luo S.M. \& Zeng R.S. (2014) Hijacking common mycorrhizal networks for herbivore-induced defence signal transfer between tomato plants.Scientific Report , 4, 3915.

Song Y.Y., Zeng R.S., Xu J.F., Li J., Shen X. \& Yihdego W.G. (2010) Interplant communication of tomato plants through underground common mycorrhizal networks. PLoS One, 5, e13324.

Stringlis I.A., Proietti S., Hickman R., Van Verk M.C., Zamioudis C. \& Pieterse C.M. (2018) Root transcriptional dynamics induced by beneficial rhizobacteria and microbial immune elicitors reveal signatures of adaptation to mutualists. The Plant Journal , 93, 166-180. 
Suarez J. \& Stencel A. (2020) A part-dependent account of biological individuality: why holobionts are individuals and ecosystems simultaneously. Biol Rev Camb Philos Soc.

Sugimoto K., Matsui K., Iijima Y., Akakabe Y., Muramoto S., Ozawa R., Uefune M., Sasaki R., Alamgir K.M. \& Akitake S. (2014) Intake and transformation to a glycoside of (Z)-3-hexenol from infested neighbors reveals a mode of plant odor reception and defense. Proceedings of the National Academy of Sciences, 111 , 7144-7149.

Sweeney C., Lakshmanan V. \& Bais H.P. (2017) Interplant aboveground signaling prompts upregulation of auxin promoter and malate transporter as part of defensive response in the neighboring plants. Frontiers in Plant Science, , 8, 595.

Takigahira H. \& Yamawo A. (2019) Competitive responses based on kin-discrimination underlie variations in leaf functional traits in Japanese beech (Fagus crenata ) seedlings. Evolutionary Ecology , 33, 521-531.

Tedersoo L., Bahram M. \& Zobel M. (2020) How mycorrhizal associations drive plant population and community biology. Science, $\mathbf{3 6 7}$.

Toome M., Randjarv P., Copolovici L., Niinemets U., Heinsoo K. \& Luik A. (2010) Leaf rust induced volatile organic compounds signalling in willow during the infection. Planta 232, 235-243.

Tu S., Yang R., Xu X., Chen J., Luo Q., Zhu Z., Chen H. \& Yan X. (2017) Flg22-triggered oxylipin production in Pyropia haitanensis .Phycological Research , 65, 86-93.

Tungadi T., Groen S.C., Murphy A.M., Pate A.E., Iqbal J., Bruce T.J., Cunniffe N.J. \& Carr J.P. (2017) Cucumber mosaic virus and its $2 \mathrm{~b}$ protein alter emission of host volatile organic compounds but not aphid vector settling in tobacco. Virology Journal , 14, 1-9.

Vahabi K., Reichelt M., Scholz S.S., Furch A.C.U., Matsuo M., Johnson J.M., Sherameti I., Gershenzon J. \& Oelmuller R. (2018)Alternaria brassicae induces systemic jasmonate responses in arabidopsis which travel to neighboring plants via aPiriformsopora indica hyphal network and activate abscisic acid responses. Frontiers in Plant Science, $9,626$.

van Dam N.M. \& Bouwmeester H.J. (2016) Metabolomics in the rhizosphere: tapping into belowground chemical communication. Trends in Plant Science, 21 , 256-265.

van Doan C., Zust T., Maurer C., Zhang X., Machado R.A.R., Mateo P., Ye M., Schimmel B.C.J., Glauser G. \& Robert C.A.M. (2020) Tissue-specific volatile-mediated defense regulation in maize leaves and roots.

van Doorn M.M., Merl-Pham J., Ghirardo A., Fink S., Polle A., Schnitzler J.P. \& Rosenkranz M. (2020) Root isoprene formation alters lateral root development. Plant 83 Cell Environment .

Van West P.v., Morris B., Reid B., Appiah A.A., Osborne M., Campbell T., Shepherd S. \& Gow N.A.R. (2002) Oomycete plant pathogens use electric fields to target roots. Molecular plant-microbe interactions ,15, 790-798.

Vannier N., Bittebiere A.-K., Mony C. \& Vandenkoornhuyse P. (2020) Root endophytic fungi impact host plant biomass and respond to plant composition at varying spatio-temporal scales. Fungal Ecology, $\mathbf{4 4}$, 100907.

Vannier N., Mony C., Bittebiere A.-K., Theis K.R., Rosenberg E. \& Vandenkoornhuyse P. (2019) Clonal Plants as Meta-Holobionts.mSystems , 4 , e00213-00218.

Veen C., Fry E., ten Hooven F., Kardol P., Morrien E. \& De Long J.R. (2019) The role of plant litter in driving plant-soil feedbacks. Frontiers in Environmental Science, 7, 168.

Vucetic A., Dahlin I., Petrovic-Obradovic O., Glinwood R., Webster B. \& Ninkovic V. (2014) Volatile interaction between undamaged plants affects tritrophic interactions through changed plant volatile emission. Plant signaling $\mathcal{E}$ behavior, $\mathbf{9}$, e29517. 
Wang C.H., Wu L., Wang Z., Alabady M.S., Parson D., Molumo Z. \& Fankhauser S.C. (2020a) Characterizing changes in soil microbiome abundance and diversity due to different cover crop techniques.PloS One, 15 , $\mathrm{e} 0232453$.

Wang K., Liu J., Zhan Y. \& Liu Y. (2019) A new slow-release formulation of methyl salicylate optimizes the alternative control of Sitobion avenae (Fabricius)(Hemiptera: Aphididae) in wheat fields. Pest Management Science, $\mathbf{7 5}, 676-682$.

Wang Z., Li Y., Li T., Zhao T. \& Liao Y. (2020b) Conservation tillage decreases selection pressure on community assembly in the rhizosphere of arbuscular mycorrhizal fungi. Science of the Total Environment ,710: 136326 .

Waters M.T., Gutjahr C., Bennett T. \& Nelson D.C. (2017) Strigolactone signaling and evolution. Annual Review of Plant Biology ,68 , 291-322.

Wenig M., Ghirardo A., Sales J.H., Pabst E.S., Breitenbach H.H., Antritter F., Weber B., Lange B., Lenk M., Cameron R.K., Schnitzler J.P. \& Vlot A.C. (2019) Systemic acquired resistance networks amplify airborne defense cues. Nat Commun, $\mathbf{1 0}, 3813$.

Wu D., Qi T., Li W.X., Tian H., Gao H., Wang J., Ge J., Yao R., Ren C., Wang X.B., Liu Y., Kang L., Ding S.W. \& Xie D. (2017) Viral effector protein manipulates host hormone signaling to attract insect vectors. Cell Research , 27 , 402-415.

Xu H., Desurmont G., Degen T., Zhou G., Laplanche D., Henryk L. \& Turlings T.C. (2016) Combined use of herbivore-induced plant volatiles and sex pheromones for mate location in braconid parasitoids.Plant, Cell 8 Environment.

Yang J.W., Yi H.-S., Kim H., Lee B., Lee S., Ghim S.-Y. \& Ryu C.-M. (2011) Whitefly infestation of pepper plants elicits defence responses against bacterial pathogens in leaves and roots and changes the below-ground microflora. Journal of Ecology, 99 , 46-56.

Yang M., Zhang Y., Qi L., Mei X., Liao J., Ding X., Deng W., Fan L., He X., Vivanco J.M., Li C., Zhu Y. \& Zhu S. (2014) Plant-plant-microbe mechanisms involved in soil-borne disease suppression on a maize and pepper intercropping system. PLoS One, 9, e115052.

Ye M., Glauser G., Lou Y., Erb M. \& Hu L. (2019) Molecular dissection of early defense signaling underlying volatile-mediated defense regulation and herbivore resistance in rice. The Plant Cell ,31 , 687-698.

Yi H.S., Heil M., Adame-Alvarez R.M., Ballhorn D.J. \& Ryu C.M. (2009) Airborne induction and priming of plant defenses against a bacterial pathogen. Plant Physiology , 151 , 2152-2161.

Zebelo S.A., Matsui K., Ozawa R. \& Maffei M.E. (2012) Plasma membrane potential depolarization and cytosolic calcium flux are early events involved in tomato (Solanum lycopersicon) plant-to-plant communication. Plant science, $196,93-100$.

Zhang H., Kim M.S., Krishnamachari V., Payton P., Sun Y., Grimson M., Farag M.A., Ryu C.M., Allen R., Melo I.S. \& Pare P.W. (2007) Rhizobacterial volatile emissions regulate auxin homeostasis and cell expansion in Arabidopsis . Planta, 226, 839-851.

Zhang P.J., Broekgaarden C., Zheng S.J., Snoeren T.A., van Loon J.J., Gols R. \& Dicke M. (2013) Jasmonate and ethylene signaling mediate whitefly-induced interference with indirect plant defense in Arabidopsis thaliana. New Phytologist, 197, 1291-1299.

Zhang Y.C., Zou Y.N., Liu L.P. \& Wu Q.S. (2019) Common mycorrhizal networks activate salicylic acid defense responses of trifoliate orange (Poncirus trifoliata). Journal of integrative plant biology ,61 , 10991111.

Zhou C., Ma Z., Lu X., Zhu L. \& Yan C. (2020) Pseudomonas fluorescens MZ05 Enhances Resistance against Setosphaeria turcica by Mediating Benzoxazinoid Metabolism in the Maize Inbred Line Anke35. Agriculture 
, 10,32 .

Zhou Y., Cen H., Tian D., Wang C. \& Zhang Y. (2019) A tomato and tall fescue intercropping system controls tomato stem rot. Journal of Plant Interactions , 14, 637-647.

Zhuang H., Li J., Song J., Hettenhausen C., Schuman M.C., Sun G., Zhang C., Li J., Song D. \& Wu J. (2018) Aphid (Myzus persicae) feeding on the parasitic plant dodder (Cuscuta australis) activates defense responses in both the parasite and soybean host. New Phytologist , 218 , 1586-1596.

\section{Figure Legends}

Figure 1. Wired and wireless phytobiome communication. Clonal plants (right) communicate via physical connections (e.g., stolons and rhizomes) or VOCs. Plants also communicate via dodder and mycorrhiza (left). Reciver plants can act as nodes to transfer defense signals against pests and pathogens to neighboring conspecific and heterospecific plants. Volatiles and root exudates recived by neighboring plants modulate receiver plant defense systems, attract parasitoids and entemopathogens, and induce plant microbiome remodeling to protect plants against imminent stress conditions.

Figure 2. Illustration of the signal input-transfer-output model in plant-plant communication. Molecular patterns, volatiles, and effector proteins of pests and pathogens elicit plant signaling pathways that promote volatiles emission and root exudation. Plant signals can be delivered to neighboring plants through the atmosphere or soil (wireless communication), or transferred through mycorrhiza, fungi, and odder (wired communication). Signals can be converted to their active form by receiver plant proteins. Signal perception by neighbor plants activates signaling pathways and phosphorylation cascades, which subsequently induce the expression of defense-related proteins and metabolites. Signal perception also changes the root exudate and recruits beneficial microbes. MAMPs, microbe-associated molecular patterns; HAMPs, herbivore-associated molecular patterns; VOCs, volatile organic compounds; GLVs, green leaf volatiles; BZ, benzoxazinoid; SA, salicylic acid; MeSA, methyl salicylate; JA, jasmonic acid; MEP, methylerythritol phosphate; MVA, mevalonic acid; MAPKs, mitogen-activated protein kinases; TFs, transcription factors.

Figure 3. Signals from neighboring plants modulate signaling pathways in receiver plants and induce microbiome remodeling. Signals can be sensed by reciver proteins (e.g., ETR1 sensor for ethylene) or coverted to active signals [e.g., SABP2 for salicylic acid (SA)]. Signals are transmitted through well-characterized downstream pathways that may cross-talk with each other. These signaling pathways regulate defense mechanisms against different groups of attackers and induce plant microbiome remodeling by changing root exudation, thereby adapting the plant holobiome to respond to imminent threats. MeSA, methyl salicylate; $\mathrm{SABP}_{2}$, SA-BINDING PROTEINS 2; NPR, NON-EXPRESSER OF PR genes; G3P, glycerol-3-phosphate; ETR1, ETHYLENE RESPONSE 1; EIN2, ETHYLENE INSENSITIVE 2; CTR1, CONSTITUTIVE TRIPLE RESPONSE 1; ORA59, OCTADECANOID-RESPONSIVE ARABIDOPSIS 59; MeJA, methyl jasmonate; Med25, Mediator 25; JAZ, JASMONATE ZIM DOMAIN protein;

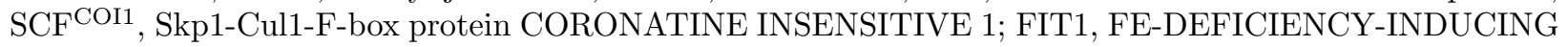
TRANSCRIPTION FACTOR1; FRO2, FERRIC REDUCTASE OXIDASE 2; IRT1, IRON-REGULATED TRANSPORTER 1; IAA, indole-3-acetic acid; AUX1/LAX, AUXIN RESISTANT 1/LIKE AUX1; ALMT1, ALUMINUM-ACTIVATED MALATE TRANSPORTER; CDPK, $\mathrm{Ca}^{2+}$-dependent proteinkinases; CIPK, calcineurin $\mathrm{B}$ like proteins (CBL)-interacting protein kinase. 

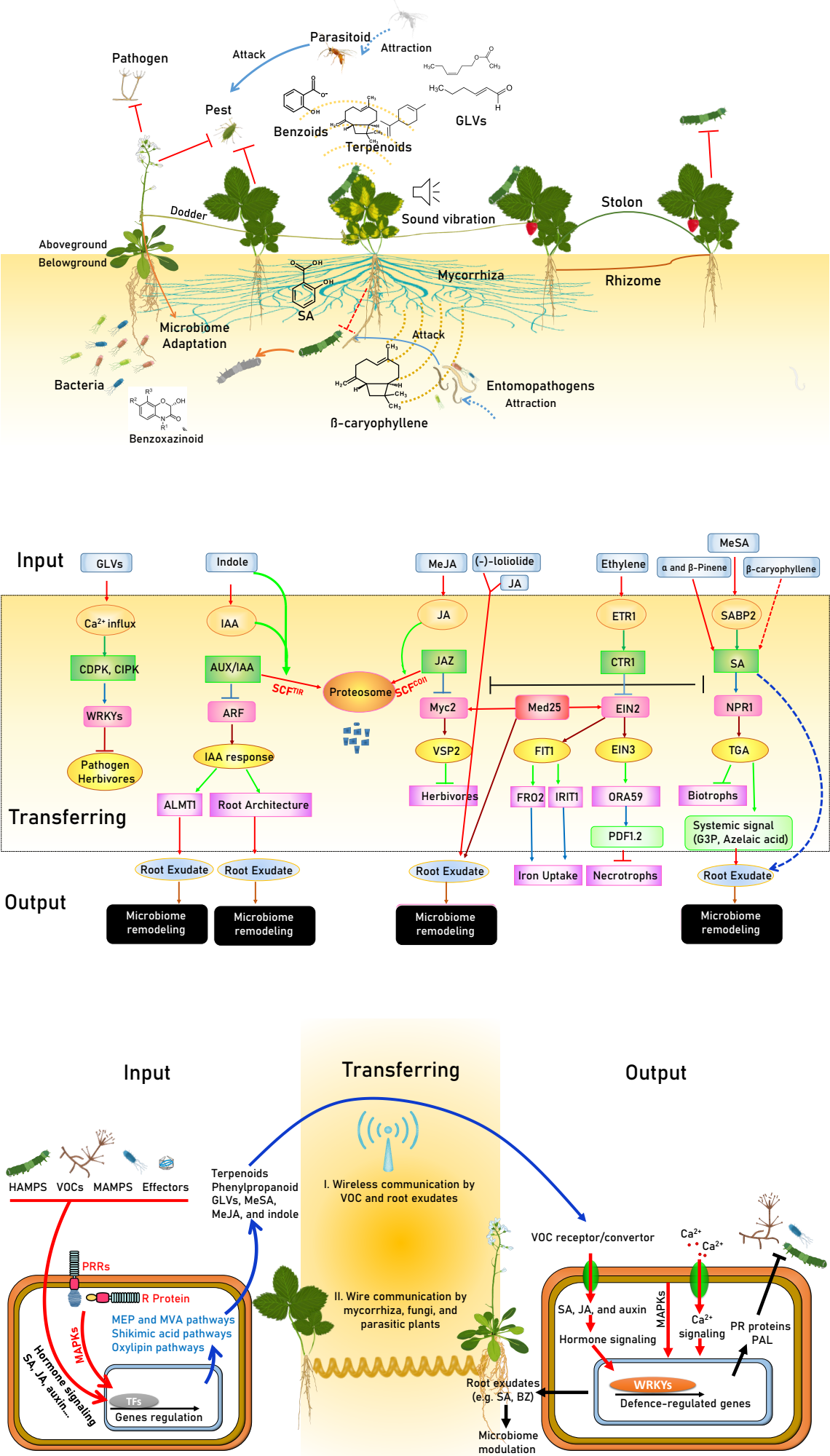